\title{
Genetic associations of the response to inhaled corticosteroids in asthma: a systematic review
}

\author{
Ozlem Keskin ${ }^{1}$, Niloufar Farzan², Esra Birben ${ }^{3}$, Hayriye Akel ${ }^{4}$, Cagatay Karaaslan ${ }^{4}$, \\ Anke H. Maitland-van der Zee ${ }^{2,5}$, Michael E. Wechsler ${ }^{6}$, Susanne J. Vijverberg ${ }^{2}$ and Omer Kalayci ${ }^{3^{*}} \mathbb{C}$
}

\begin{abstract}
There is wide variability in the response to inhaled corticosteroids (ICS) in asthma. While some of this heterogeneity of response is due to adherence and environmental causes, genetic variation also influences response to treatment and genetic markers may help guide treatment. Over the past years, researchers have investigated the relationship between a large number of genetic variations and response to ICS by performing pharmacogenomic studies. In this systematic review we will provide a summary of recent pharmacogenomic studies on ICS and discuss the latest insight into the potential functional role of identified genetic variants. To date, seven genome wide association studies (GWAS) examining ICS response have been published. There is little overlap between identified variants and methodologies vary largely. However, in vitro and/or in silico analyses provide additional evidence that genes discovered in these GWAS (e.g. GLCCI1, FBXL7, T gene, ALLC, CMTR1) might play a direct or indirect role in asthma/treatment response pathways. Furthermore, more than 30 candidate-gene studies have been performed, mainly attempting to replicate variants discovered in GWAS or candidate genes likely involved in the corticosteroid drug pathway. Single nucleotide polymorphisms located in GLCCI1, NR3C1 and the 17921 locus were positively replicated in independent populations. Although none of the genetic markers has currently reached clinical practise, these studies might provide novel insights in the complex pathways underlying corticosteroids response in asthmatic patients.
\end{abstract}

Keywords: Inhaled corticosteroids, Asthma, Genetics, Genomics, GWAS

\section{Introduction}

Affecting up to $18 \%$ of the world's population, asthma is a chronic airway disease and inhaled corticosteroids (ICS) are the preferred first-line treatment for persistent asthma [1]. However, there is a wide variability in response to ICS [2-4] such that up to $35-40 \%$ of the patients receiving ICS for 8-12 weeks do not show significant improvement in lung function [2, 3]. Furthermore, $10 \%$ of the asthmatic patients on maintenance ICS treatment may remain symptomatic or at high risk of asthma attacks in spite of the regular use of this medication [5]. In addition to poor adherence to medication, continuing

\footnotetext{
*Correspondence: okalayci63@gmail.com

3 Pediatric Allergy and Asthma Unit, Hacettepe University School of Medicine, 06100 Ankara, Turkey

Full list of author information is available at the end of the article
}

noxious environmental exposures, misdiagnosis, and truly steroid refractory disease, genetic variation might also be an important factor influencing treatment response in patients with asthma [4, 6-8]. Approximately $70 \%$ of the variance in ICS response is suggested to be due to genetic factors $[4,9]$.

Over the past three decades, researchers have investigated the relationship between a large number of genetic variations and response to ICS by performing pharmacogenomic studies. The main aim of these studies was to identify genetic markers that could help physicians optimize asthma treatment. The high number of publications has enabled systematic literature reviews that summarize the findings of the studies and evaluate the potential clinical relevance of the findings. One of these systematic literature reviews was published by Farzan et al. [10]. This 
study reviewed pharmacogenomics studies of ICS and leukotriene modifiers that were published between 1999 and 2015. Furthermore, SNPs that were positively replicated at least once in an independent population were discussed in detail. Despite the large number of pharmacogenomics studies, there is still no genetic marker used in clinical practice to optimize asthma treatment with ICS. However, due to the rapid decrease in the costs of genotyping and emergence of advanced genotyping technologies, efforts are still ongoing to replicate previously identified markers and/or identify new genetic markers by performing Genome-wide association studies (GWAS). One of the important issues of single nucleotide polymorphisms (SNPs) that are identified by GWAS is that their function and relation to the disease/trait of interest is often not clear and therefore might inhibit further progression towards clinical implementation. This has encouraged researchers to perform in vitro and/or in silico studies to unravel the potential role of the SNPs/ genes in the asthma-treatment response pathway. Since the field is rapidly evolving, this follow-up systematic review aims to (1) provide a summary of the pharmacogenomics studies on ICS published after 2015 and (2) provide the latest insight into the potential functional role of the identified genes/variants identified in GWAS, in order to provide an overview of the latest promising clinical markers.

\section{Methods}

Articles published from 1995 January through the end of August 2018 were searched in PubMed using three keywords. Conference abstracts, articles assessing adverse drug effects and articles that had not been published in English were excluded. First, we eliminated articles from the titles, and then by abstracts. Then the remaining articles were read in full. We also screened review articles for possible missed publications.

A search using the keywords "Asthma and/or Lung function, Corticosteroids, Genetics"yielded 1106 studies; "Asthma and/or Lung function, Corticosteroids, Pharmacogenetics" yielded 93 studies; "Asthma and/or Lung function Corticosteroids Pharmacogenomics" yielded 122 studies. Of these, 46 met the inclusion criteria with 38 being candidate gene studies and 7 being GWAS and 1 being exome sequencing study (Fig. 1). Nine articles remained after excluding the studies before 2015 June.

From all the publications selected, the following data were extracted: ICS type and duration of treatment, genes and SNPs, outcome, study design, ethnic backgrounds of patients, sample size, age range and duration of the study. From GWAS, information regarding the in vitro or in silico analysis after the association analysis was extracted.
This systematic review is reported according to PRISMA guidance [11].

\section{Novel pharmacogenomics studies}

From 2015 to 2018, nine additional studies were identified through PubMed. Of these studies, three were GWAS and six were candidate gene studies.

\section{GWAS (Genome-wide association studies)}

GWAS have provided the opportunity to detect novel pharmacogenetic variants related to ICS response by scanning a high number of genetic variants across the entire genome. In the systematic review by Farzan et al. [10], the results of the four GWAS that had been conducted prior to 2015 have been described in detail. These GWAS had identified four new loci to be associated with ICS response. These loci harbored the GLCCI1 (glucocorticoid-induced transcript 1 protein), T, FBXL7 (F-box and leucine-rich repeat protein 7) and $A L L C$ (Allantoicase) genes [12-15]. SNPs within GLCCI1, T gene, and $A L L C$ were associated with changes in the lung function and rs10044254 SNP within FBXL7 was associated with changes in the asthma symptom scores. From the identified SNPs within these genes, rs 10044254 was the only SNP that reached the genome-widesignificance threshold. SNPs within the GLCCI1, T gene, and FBXL7, were associated with ICS response in pediatric asthma populations and were conducted by the same research group [12-14]. These studies included Caucasians from the Single-Nucleotide Polymorphism Health AssociationAsthma Resource Project (SHARP). Although the three GWAS all studied the SHARP population, the methods of the GWAS differed quite a lot with regard to sample size, study design, outcome measurements, and genotyping platforms.

Between 2015 and 2018, three additional GWAS were published [16-18], of which one was conducted by the SHARP group. Changes in lung function were considered as the primary outcome in two of these GWAS and asthma exacerbations were considered the primary outcome in one study. None of the new GWAS could identify the previously found genes/SNPs in candidate gene or GWAS.

In the GWAS by Wang et al. [16], 120 mild-to-moderate adult asthmatics were included. In this study, patients received different doses of glucocorticoids $(125,250,500$, $1000 \mathrm{mcg}$ ) and the dosage of ICS was increased each week. The hypothesis underlying this approach was that integration of pharmacodynamic properties of corticosteroids into pharmacogenetic GWASs containing drug responses to different doses may increase the statistical power of significant association detection [19]. For the first time, a mechanistic model was applied to analyse 


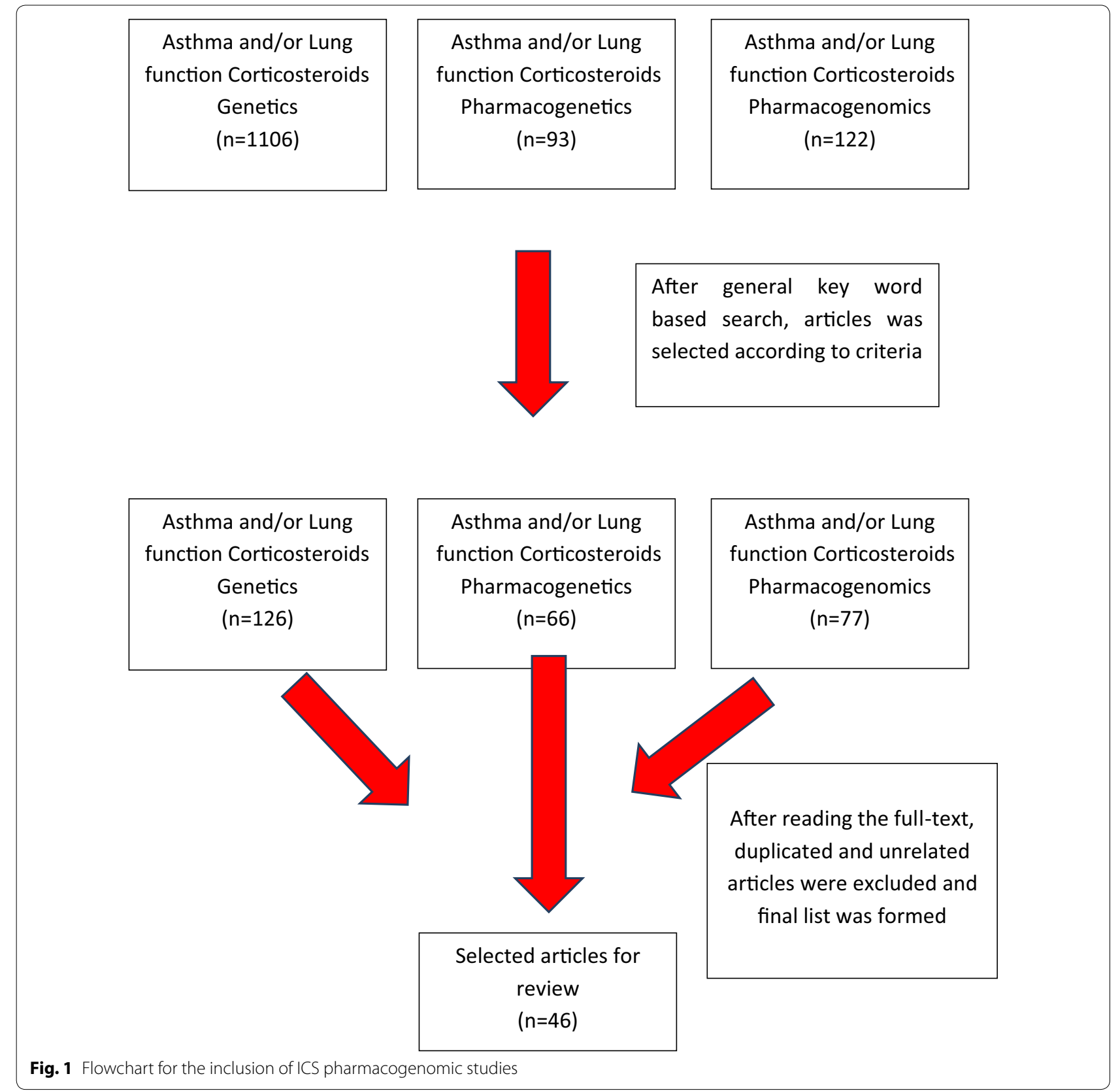

the GWAS data with a series of dose-dependent pharmacological phenotypic data and detected associations of genome-wide significance between dose-dependent pulmonary function response to ICS, and five loci: rs6924808 on chromosome $6\left(\mathrm{p}=5.315 \times 10^{-7}\right), \quad$ rs 10481450 on chromosome $8\left(\mathrm{p}=2.614 \times 10^{-8}\right)$, rs1353649 onchromosome $11\left(\mathrm{p}=3.924 \times 10^{-9}\right), \mathrm{rs} 12438740$ on chromosome $15\left(\mathrm{p}=4.499 \times 10^{-8}\right)$, and $\mathrm{rs} 2230155$ onchromosome 15 $\left(\mathrm{p}=1.798 \times 10^{-7}\right)$. These loci are mapped to candidate genes related to cellular functions [20, 21]. Asthmatics who were homozygous for the mutant alleles had
$30-300 \%$ higher \% Forced expiratory volume in one second (FEV1) values at an intermediate dose of glucocorticoids compared to the homozygotes for the wild-type alleles and heterozygotes for all of the associated SNPs (with the exception of rs6924808). Some of the SNPs were sensitive to a small change in low drug doses and some showed variation after larger dose changes. Significant associations were also demonstrated in three additional independent replication populations. Two SNPs, chr6 rs6924808 and chr11 rs1353649, displayed an increased significance level $\left(\mathrm{p}=6.661 \times 10^{-16}\right.$ and $\left.5.670 \times 10^{-11}\right)$ in 
the pooled analysis of first GWAS results with these three replication trials. This GWAS underlined the importance of the optimal ICS dose for individualized asthma treatment based on a patient's genetic makeup.

The first GWAS that studied asthma exacerbations as a primary outcome was performed by Dahlin et al. in 2015. In this study, 806 asthmatic children with Caucasian ethnicity were included from two population-based biobanks [17]. The results of the GWASs performed in these two populations were meta-analysed. However, none of the SNPs from the meta-analysis met the threshold for genome-wide significance. The most significant result was reported for 6 SNPs (rs2395672 and rs279728, rs4271056, rs6467778, rs2691529, and rs9303988) within three different genes CMTR1 (Cap methyltransferase 1), TRIM24 (Tripartite Motif Containing 24) and MAGI2 (Membrane Associated Guanylate Kinase). Among these, the rs2395672 SNP within the CMTR1 gene had the smallest $\mathrm{p}$ value from the meta-analysis [joint Odds Ratio $(\mathrm{OR})=1.07,95 \%$ CI 1.03-1.11; $\left.\mathrm{p}=2.3 \times 10^{-6}\right]$.

The latest and so far largest GWAS of ICS response has been published by Mosteller et al. [18]. In this study, 2672 patients (12 years and older) were included from seven randomized, double-blind, placebo-controlled, multicenter clinical studies that were performed in a total of 26 countries. Changes in FEV1 at week 8 and 12 following fluticasone furoate (FF) or fluticasone propionate (FP) treatment were considered as the study outcome. The analysis was performed with more than 9.8 million genetic variants (minor allele frequency $\geq 1 \%$ ), and none of the SNPs reached the genome-wide significance threshold.

An overview of published GWAS is provided in Table 1.

\section{Evidence of functional activity of the previously identified genes and SNPs in GWAS \\ GLCCI1}

GLCCI1 is a protein-coding gene located within the chromosome 7p21.3. The role of GLCCI1 as one of the target genes of glucocorticoids was described by Chapman et al. more than two decades ago. They showed an increased expression of this gene in two different cell lines upon the administration of dexamethasone [22]. Glucocorticoids can induce apoptosis in several immune-inflammatory cells such as eosinophils and lymphocytes. Therefore, researchers concluded that reduced expression of GLCCI1 because of rs37973 could result in reduced apoptosis of these cells. Consequently, reduced apoptosis of these cells could decrease ICS efficacy. To validate the functional role of the gene and its SNP in asthma control, an in vitro study was performed using lymphoblastoid B cells derived from children in the Childhood Asthma Management Program (CAMP) study
[12]. This study showed that dexamethasone significantly increased GLCCI1 expression. Specifically, in patients homozygous for the mutant allele $(G)$, the expression was significantly lower compared to homozygotes for the wild-type allele (A) in the presence of dexamethasone. Increased expression of the GLCCI1 gene was associated with a better response to ICS. Furthermore, $\mathrm{Hu}$ et al. [23] in their mRNA analysis showed an increased expression in GLCCI1 after ICS. Taken together, GG carriers appear to be less sensitive to corticosteroids at the cellular level.

\section{FBXL7}

$F B X L 7$, located in chromosome 5, is a member of Skp1Cul1-F-box complex which is involved in ubiquitylation and degradation of proteins in the cells [24, 25]. In-vitro studies show that FBXL7 induces cell apoptosis and its cellular abundance is regulated by FBX18, another SCF protein [26]. Therefore, increased FBXL7 expression can induce cell and tissue injury. In fact, studies on lung epithelial cells show that overexpression of $F B X L 7$ results in mitochondrial damage [27]. FBXL7 mediates this function through a decrease in the amount another protein (survivin) involved in cell survival and apoptosis. To date, more than 50 F-box proteins have been identified and these proteins appear to play major roles in inflammation and immunity by interacting with each other [28, 29]. A study in murine lung epithelial cells showed that F-box family members interact with proteins that can induce cytokine release in immune cells [26]. In the GWAS of asthma symptoms by Park et al. [14], the variant allele of the rs10044254 SNP was associated with poor symptom control. A further in vitro analysis using immortalized B cells obtained from the CAMP participants demonstrated that the variant allele was associated with a decrease in $F B X L 7$ expression in response to dexamethasone. Although not statistically significant, increased dexamethasone-induced expression of FBXL7 was associated with poor asthma symptom scores. Despite these promising findings, no further studies have tried to elucidate the role of these proteins in asthma control.

\section{Tgene}

$T$ gene, located within the chromosome 6 , is a member of the genes containing the $\mathrm{T}$ locus as a common protein motif [30]. The product of the $\mathrm{T}$ locus seems to be involved in the development of all vertebrate organisms. Furthermore, $T$ gene expression has been previously shown in healthy adult lung tissue. In the GWAS study by Tantisira et al., researchers performed a pathway analysis in order to unravel the potential influence of the $\mathrm{T}$ gene on response to corticosteroids. To that end, using the program GeneMANIA (http://genemania.org/), they focused on the T gene-NR3C1 (Nuclear Receptor 


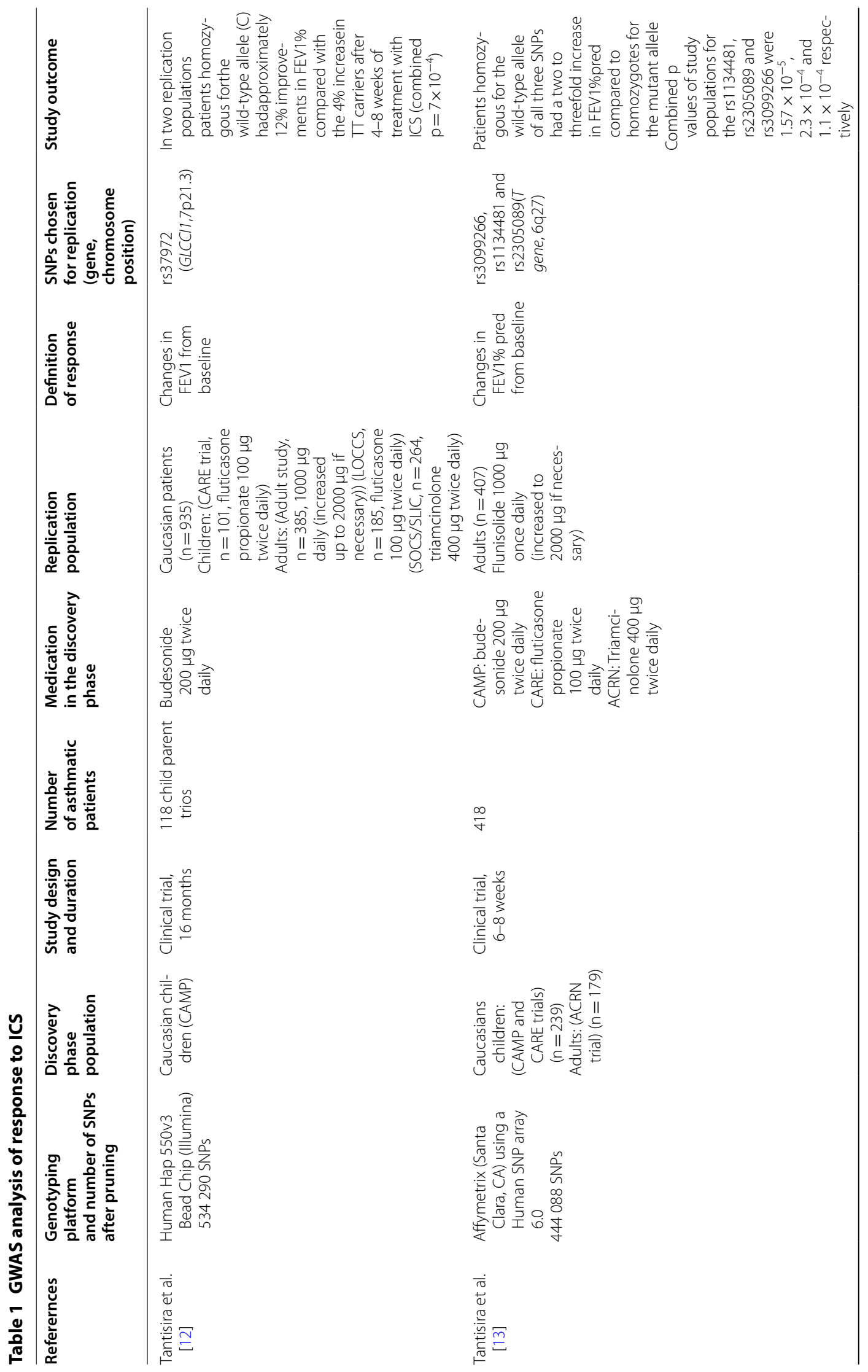




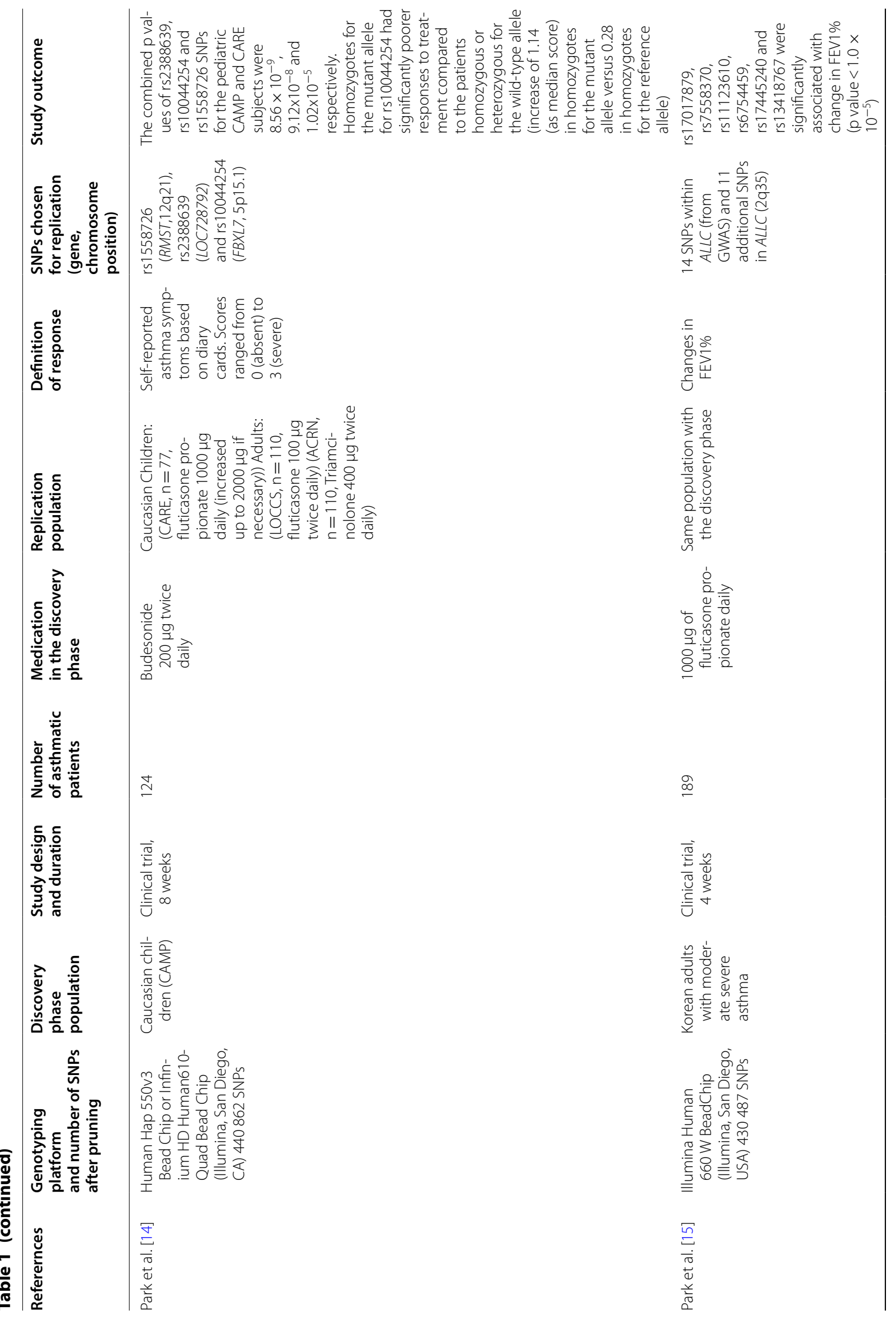




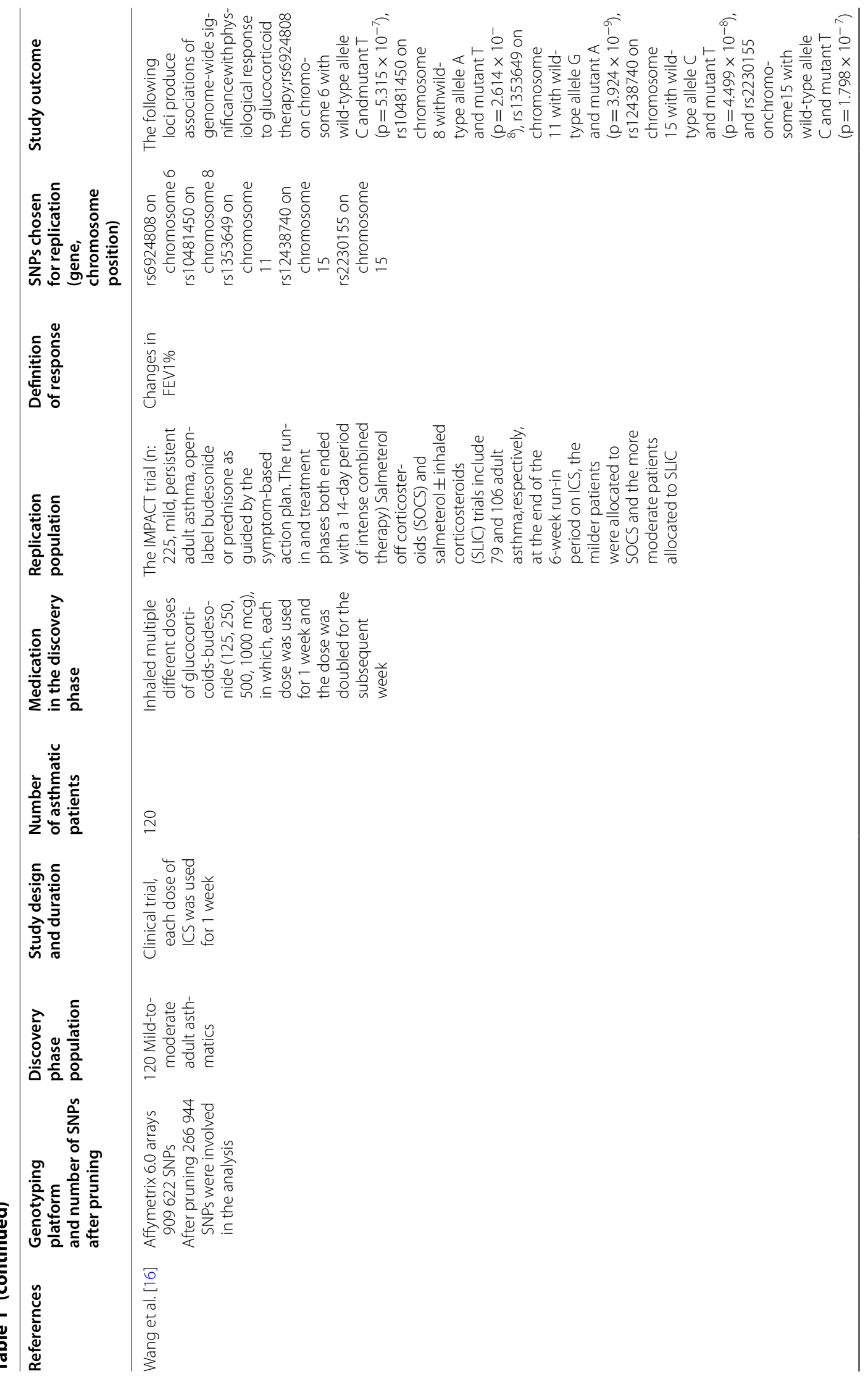




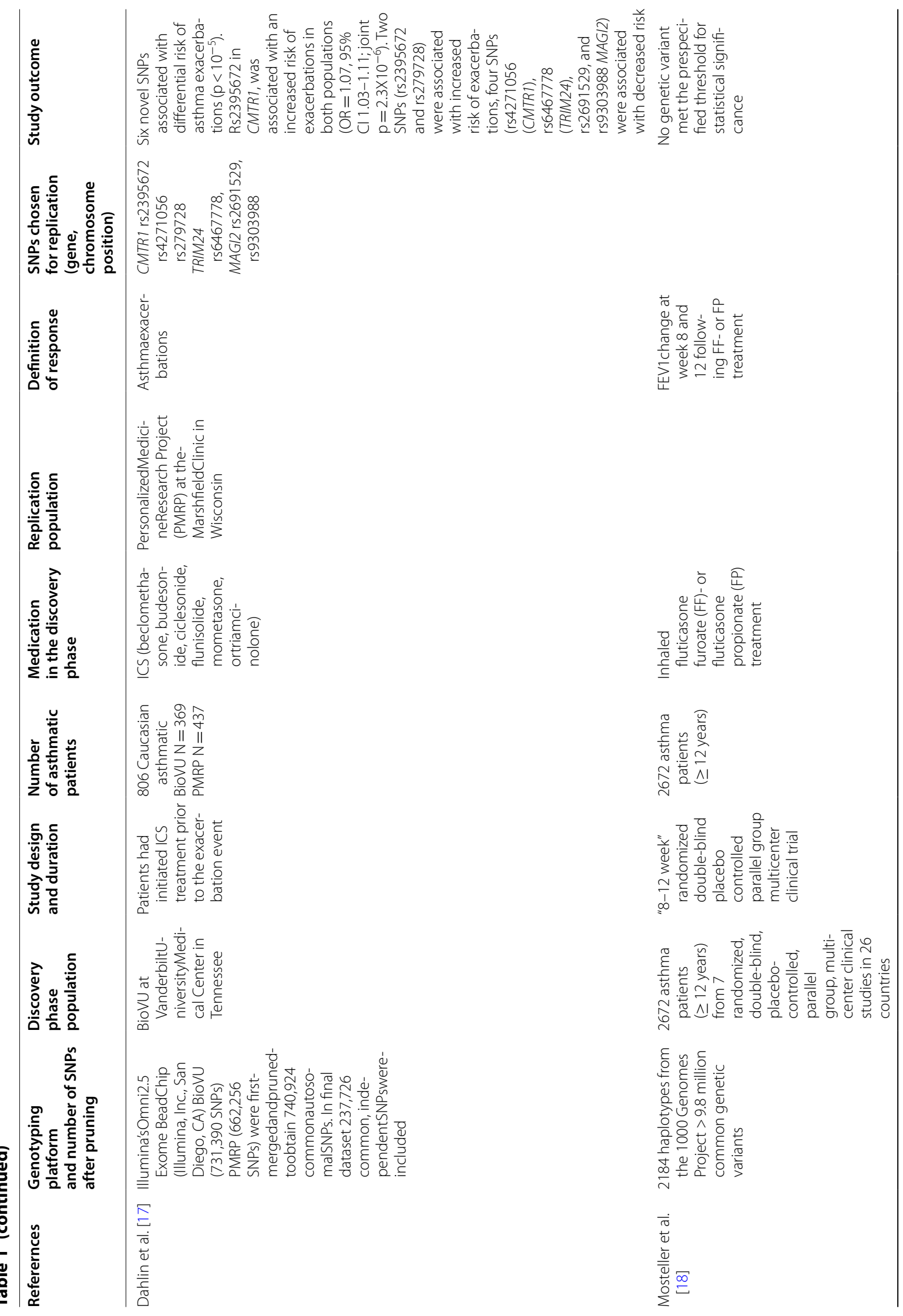




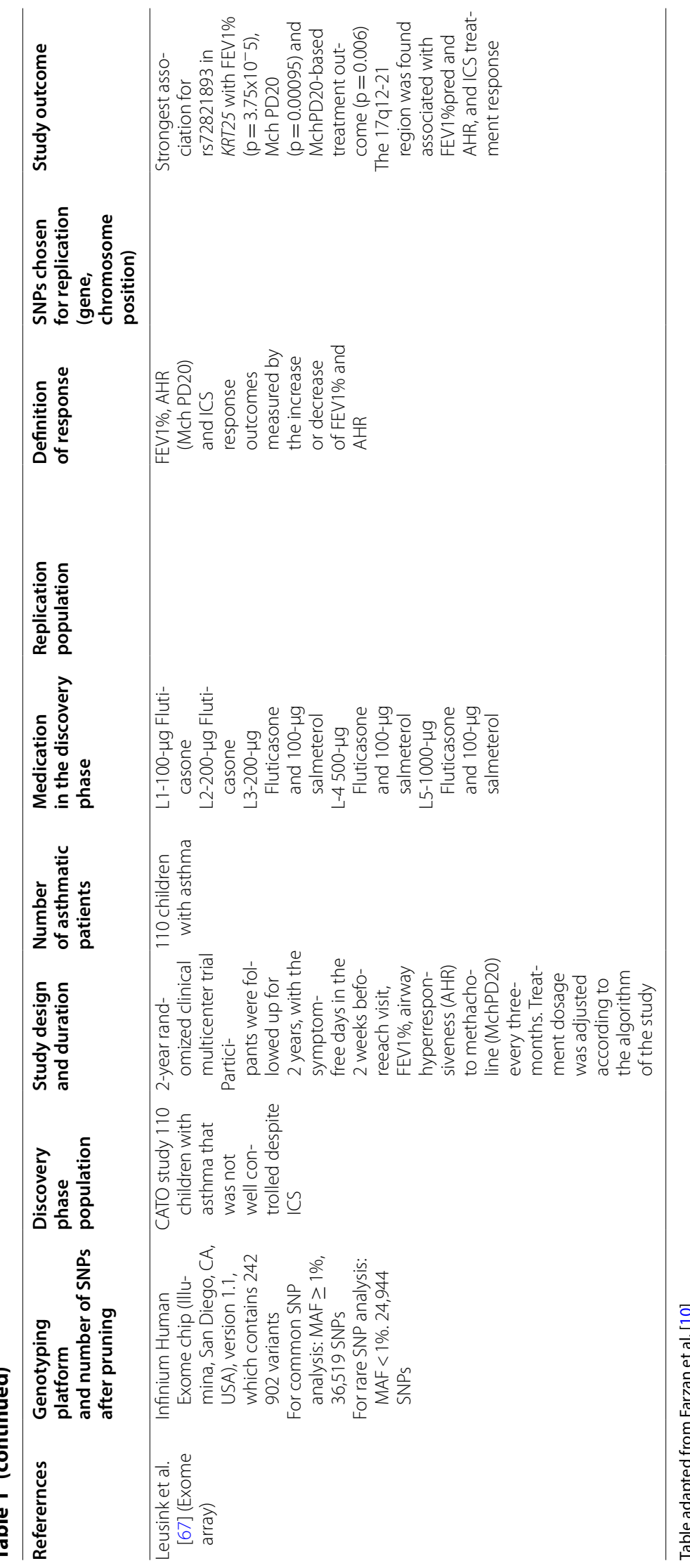


Subfamily 3 Group C Member 1) interactions [13]. The results showed that the $T$ gene is co-expressed with the NRIP1, FOXA2, and TTPA genes. The same analysis showed that these genes directly interact or are predicted to interact with NR3C1.

Considering the important role of corticosteroids in lung development, it has been suggested that alterations in corticosteroid-responsive genes during development mighthave an influence on bothasthma susceptibilityand treatment response. Previous studies have shown that a decrease in $\mathrm{T}$ gene expression inhibits chondrogenesis, the process of cartilage development, mediated by BMP2 and FGFR3 [31]. These two proteins have been shown to be associated with corticosteroids resistance [32, 33]. As suggested by Tantisira et al. [13], these findings might provide a mechanistic basis for the $\mathrm{T}$ gene in response to ICS. However, despite these findings no further studies have tried to explore the functional role of this gene in ICS response.

\section{ALLC}

The study by Park et al. [15], was the first study ever to report an association between the $A L L C$ gene and a disease or treatment response. By performing in silico analysis, Park et al. reported correlations between the $A L L C$ function and three SNPs (rs13418767, rs6754459, and rs13409104) in high LD with the most significant SNP (rs11123610) from the GWAS. Furthermore, using the TFSEARCH program, they showed that rs 13418767 is a binding site for Sp1, a member of the Skp1-Cul1-Fbox complex. A recent study that investigated the association between occupational exposure to pesticides and genome-wide DNA methylation sites found differential DNA methylation in the $A L L C$ gene [34]. In patients with airway obstruction who were exposed to high doses of pesticides, two different CpG sites of the ALLC gene were significantly hypo-methylated. ALLC is an enzyme that has lost its uricolytic activity during vertebrae evolution. However, animal studies suggest rather than a nonfunctionality, there seems to be low expression level and low substrate affinity of this gene in animals [35]. There is limited knowledge regarding the role of this gene and its variations on asthma and treatment response. While $A L L C$ located within chromosome 2 seems to have a lost function in humans, this chromosome harbors several genes that have been found to be associated with FEV1 $[36,37]$ and IgE levels [38].

\section{CMTR1}

CMTR1, located within the chromosome $6 \mathrm{p} 21$, is involved in mRNA capping [39]. Capping of mRNA stimulates the stability of mRNA and increases efficient mRNA translation [40]. Furthermore, the product of this gene (hMTr1) is involved in defense mechanisms against viral infections. Increased CMTR1 expression has been found to be associated with $\mathrm{T}$ cell mediated immune response mechanisms in human peripheral blood mononuclear cells [41]. Using independent microarrays, Dahlin et al. [17], evaluated the expression level of the top genes identified in their GWAS. They collected nasal lavage samples from children during and 1-2 weeks after asthma exacerbations. The expression level of CMTR1, but not TRIM24 or MAGI2,was significantly reduced 1-2 weeks after exacerbations. Since viral infections are the main causes of asthma exacerbations in children and expression of CMTR1 has been shown to be upregulated in children during asthma exacerbations [42], this gene and its product might be promising new therapeutic targets that treat viral infections.

\section{Candidate gene studies}

In total 29 candidate gene studies were included in the systematic review by Farzan et al. [10]. In summary, SNPs within the CRHR1 (Corticotropin Releasing Hormone Receptor 1), GLCCI1, FCER2 [Fc fragment of IgE, low-affinity II, receptor for (CD23)], NR3C1, STIP1, and TBX21(T-box 21) were studied the most. However, despite the large number of studied SNPs $(>500)$ within 120 genes, the most consistent results were reported only for one SNP, rs28364072, within the FCER2 gene. rs28364072 was significantly associated with all three outcomes (lung function, symptoms, and exacerbations) in pediatric asthma populations.

Between 2015 and 2018, six additional candidate gene studies were published. These studies attempted to replicate the previously studied markers within the GLCCI1 [23, 43-45]; ADRB2 (Adrenoceptor Beta 2) [46, 47], NR3C1 [43], CRHR1 [43], 17q21 locus [48] and TBX21 [43]. SNPs located in the GLCCI1, NR3C1, and 17q21 were positively replicated in independent populations. An overview of replicated candidate gene studies is provided in Table 2 [23, 43-61].

\section{Replicated genes and SNPs GLCCI1 (glucocorticoid induced 1)}

By 2015, three candidate gene studies had studied GLCCI1 in order to replicate the findings of a GWAS published by Tantisira et al. [12]. In short, the GLCCI1 rs37973 was positively replicated only in one of the three candidate gene studies. The positive replication study included 224 adult asthmatic patients of Japanese ethnicity. The SNP was significantly associated with an annual decline in FEV1 of $30 \mathrm{ml} /$ year or greater [54]. After 2015, four additional studies, including one study by our own research group, have assessed the association between rs37973 SNP and ICS response [23, 43-45]. 


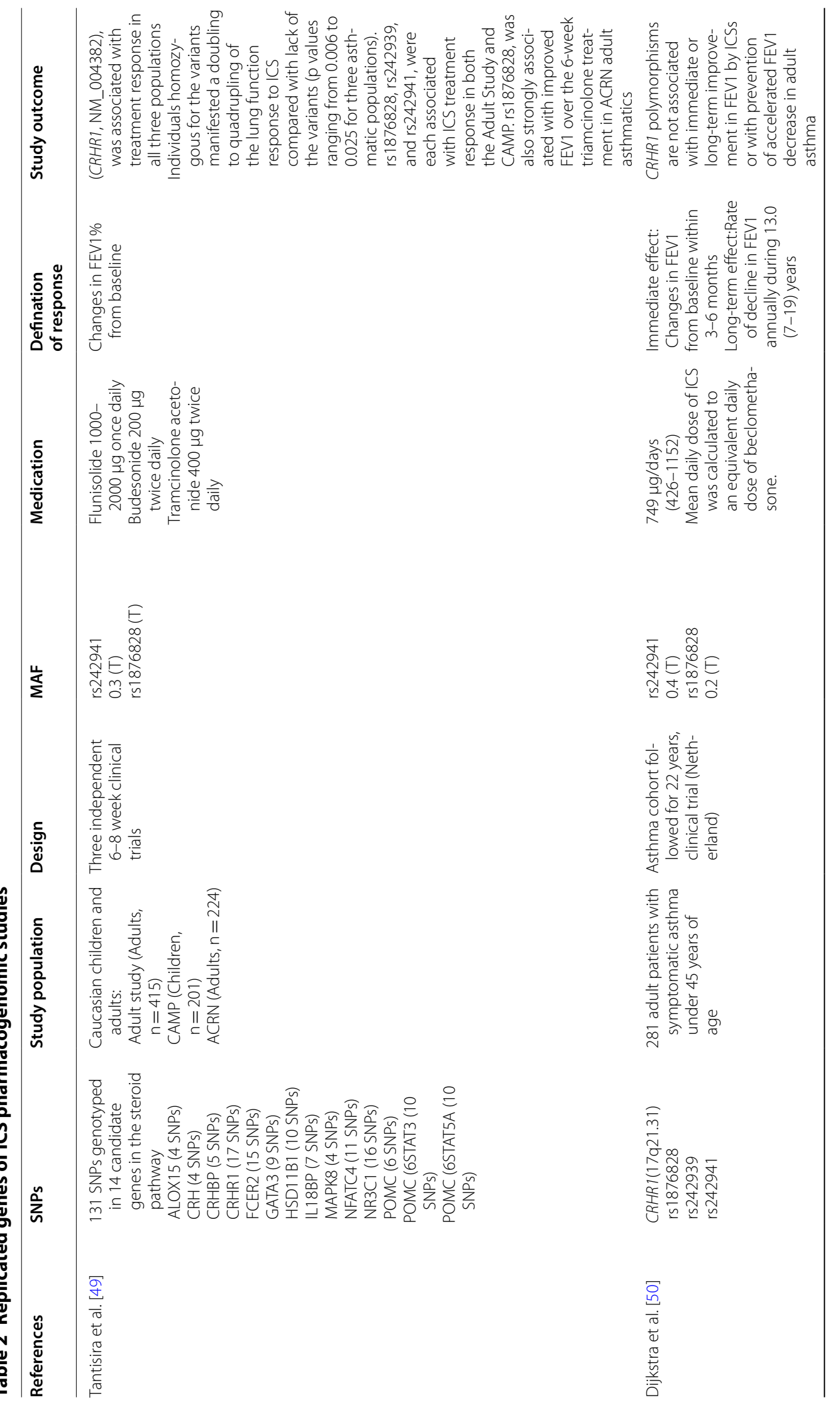




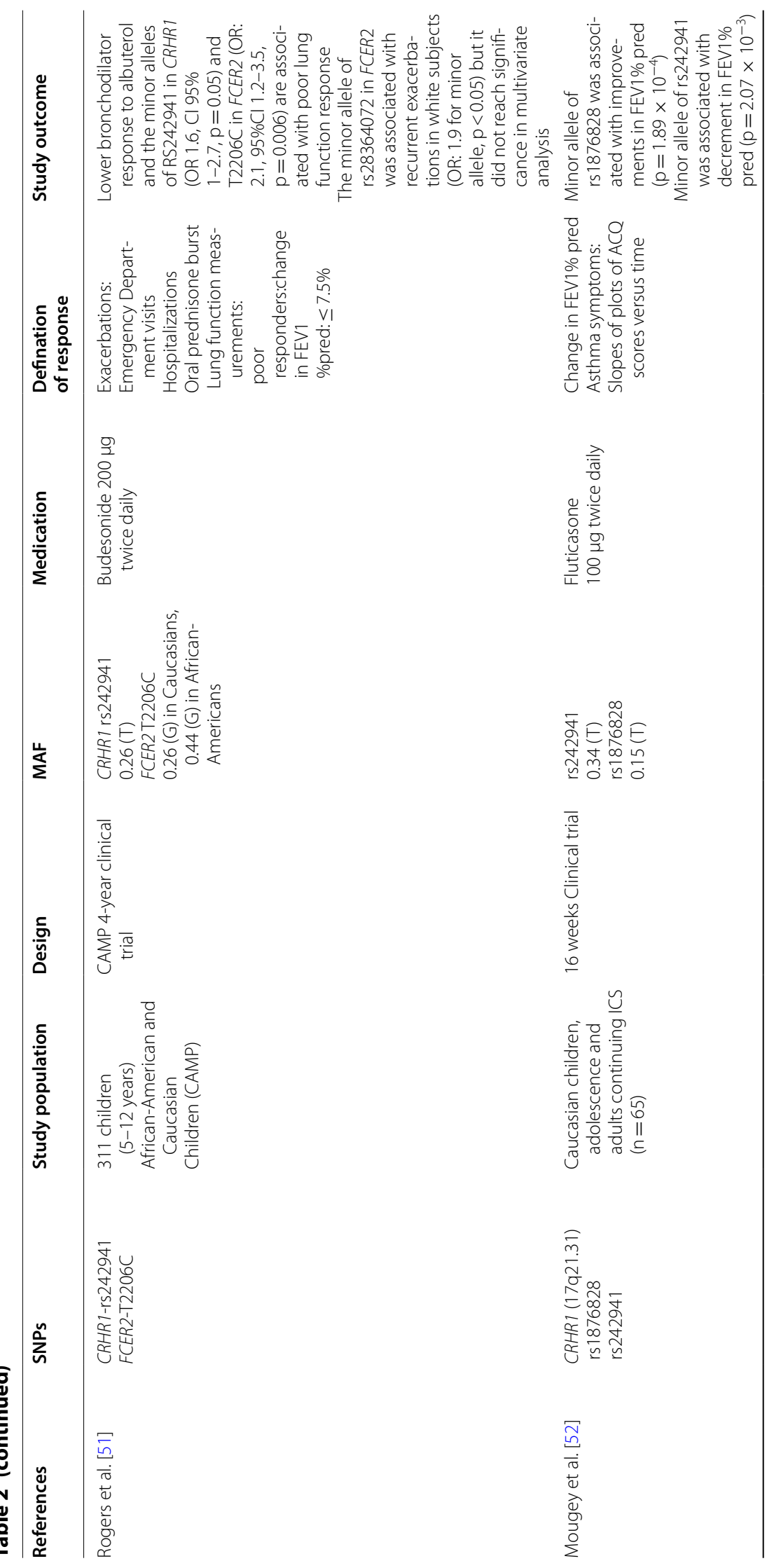




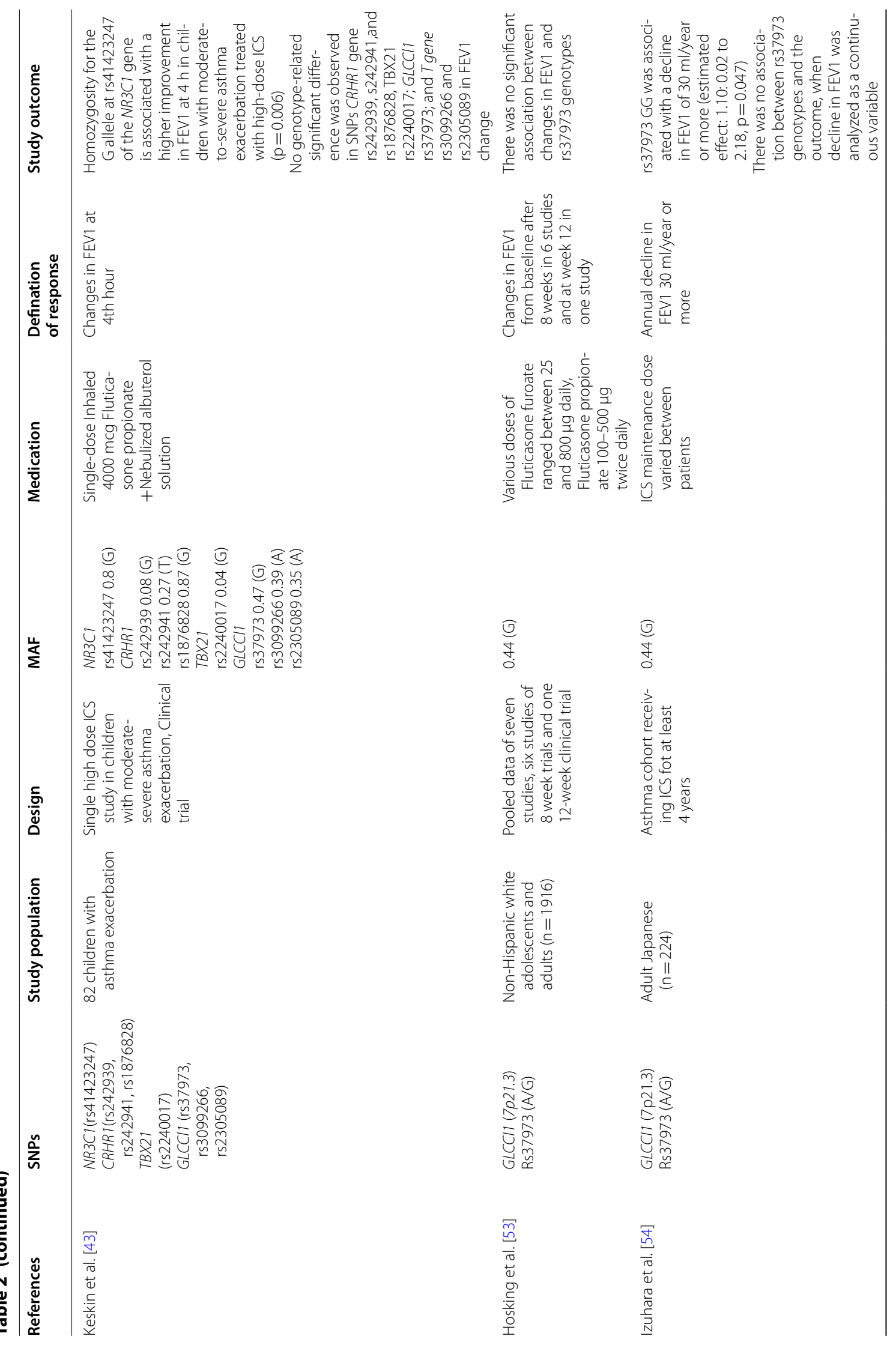




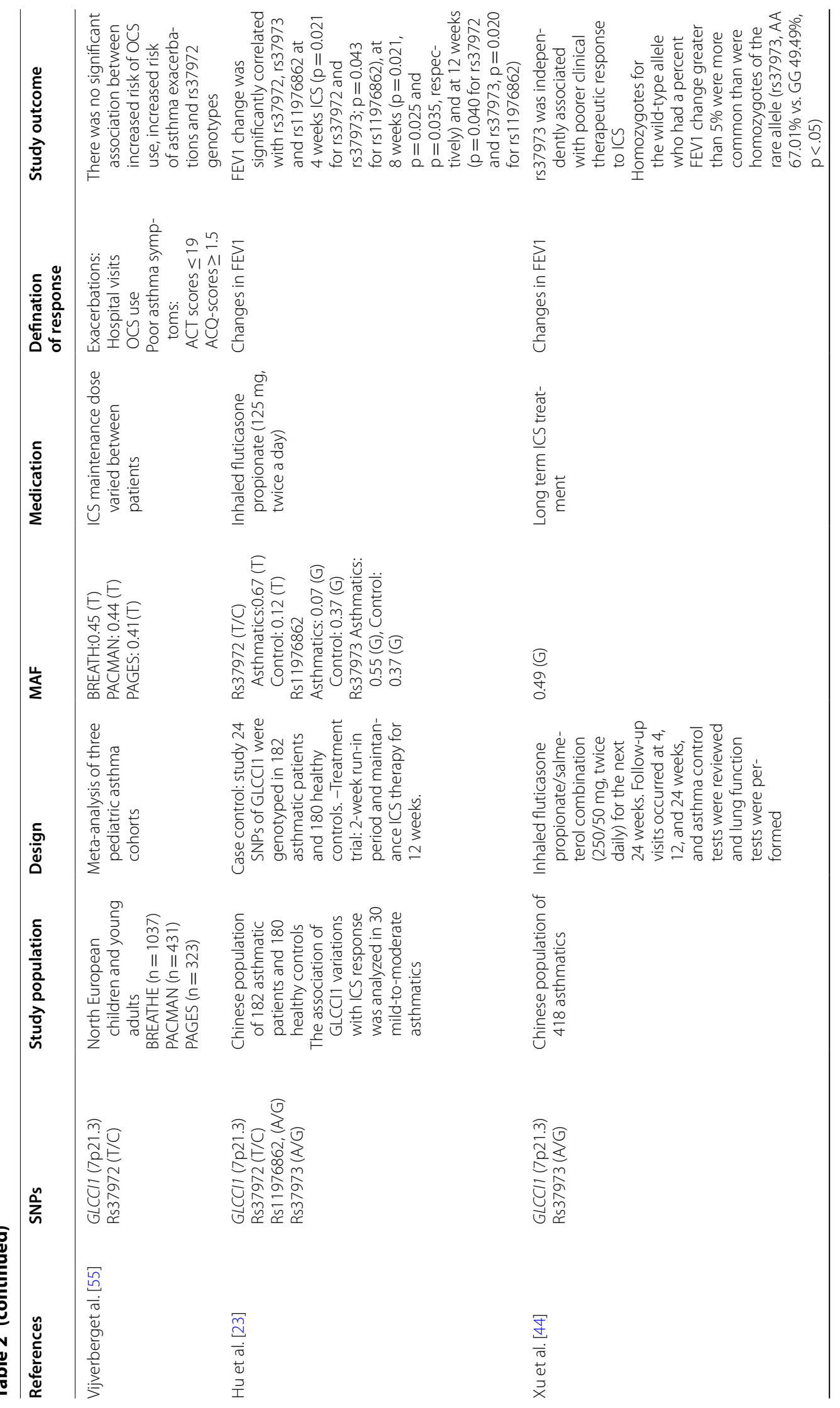




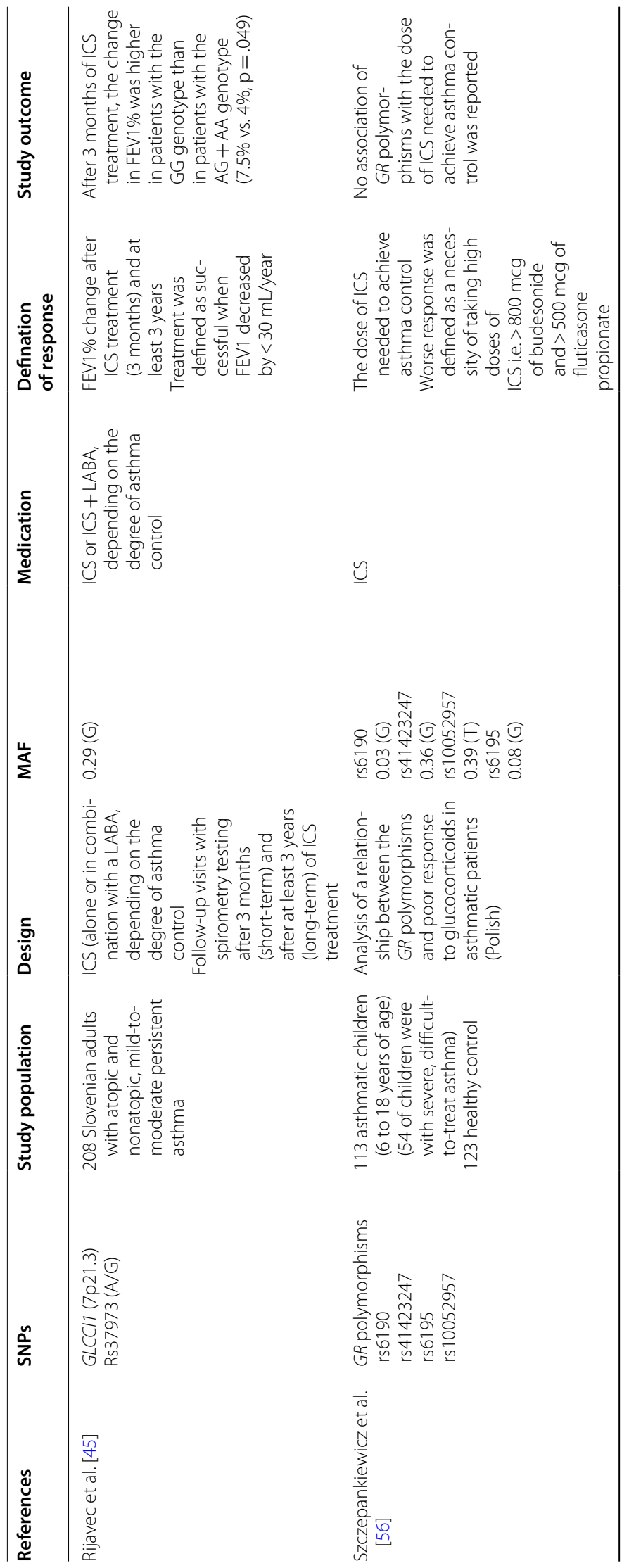




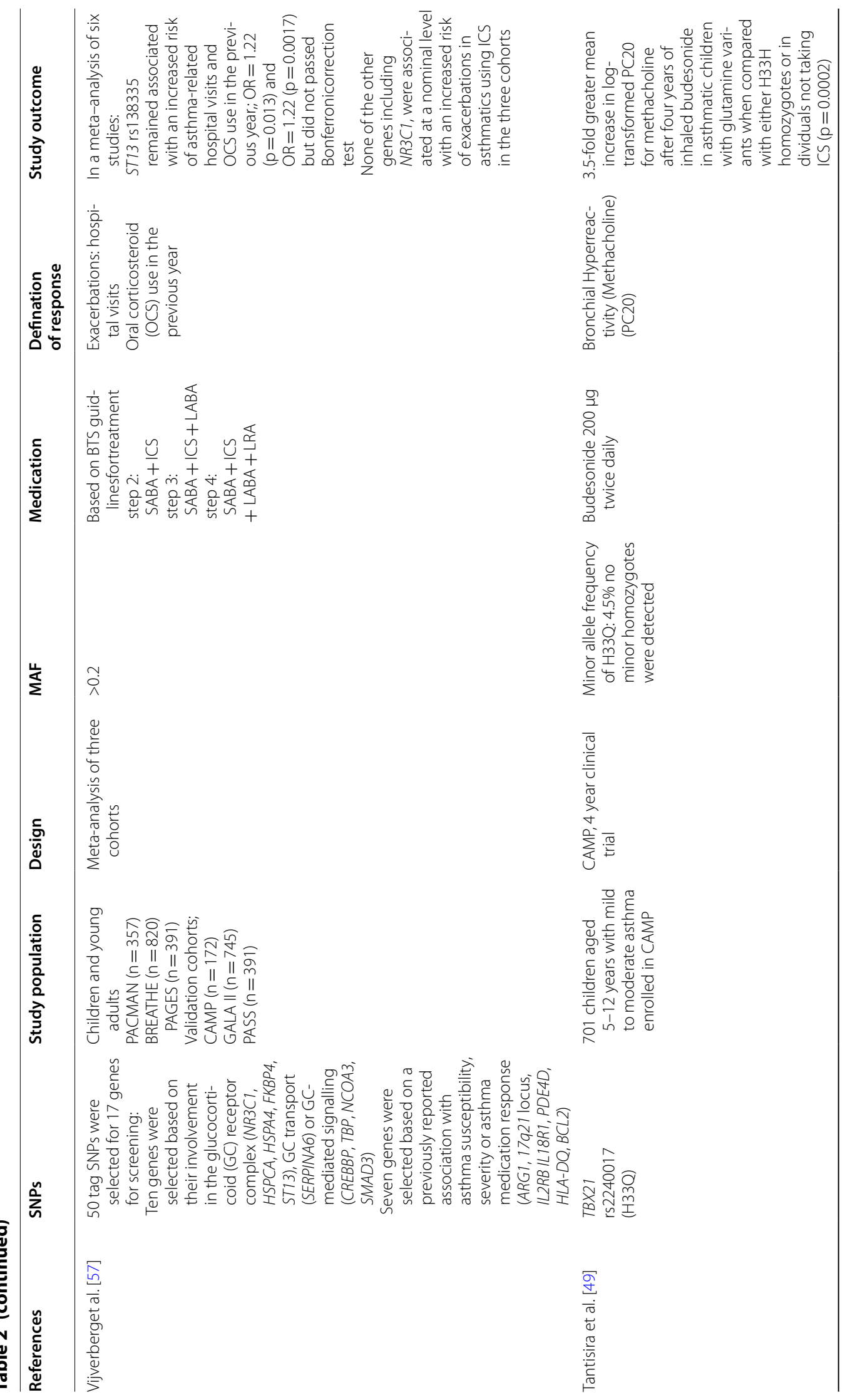




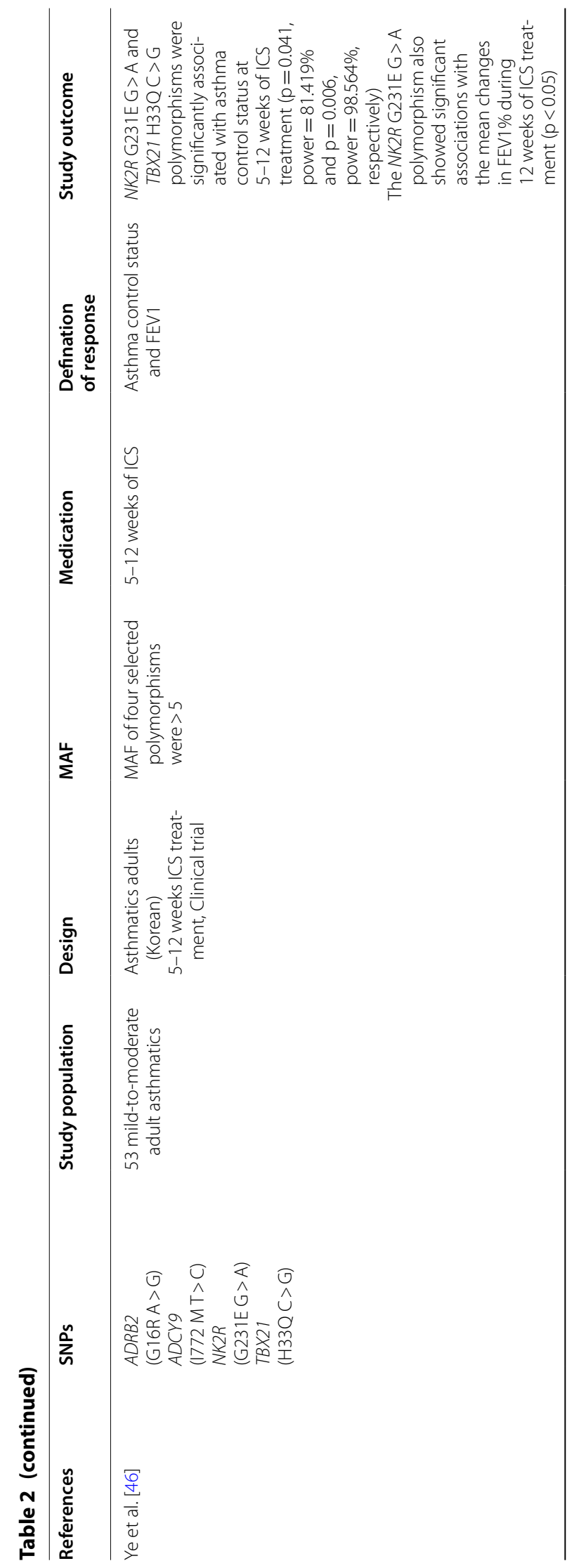




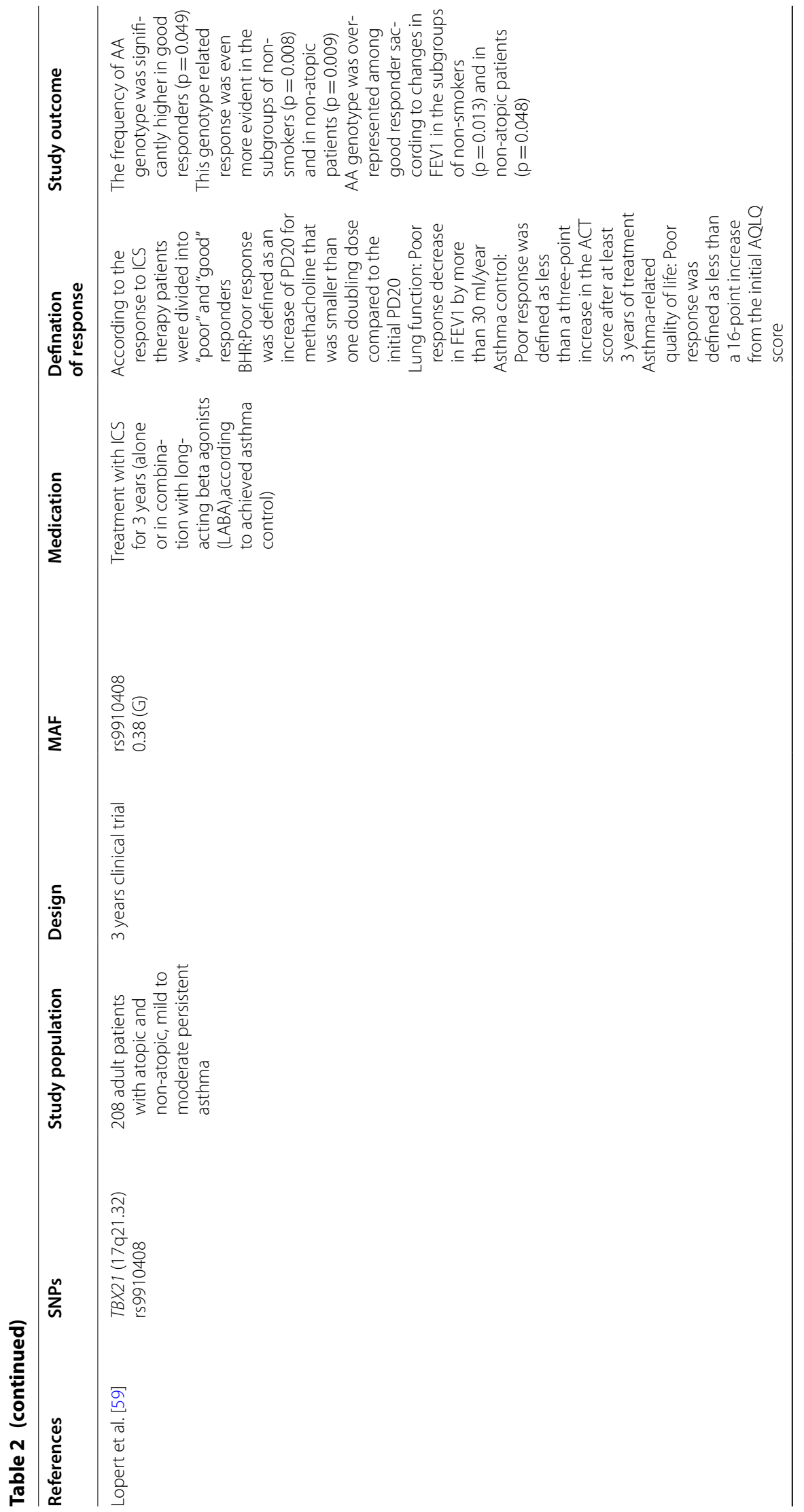




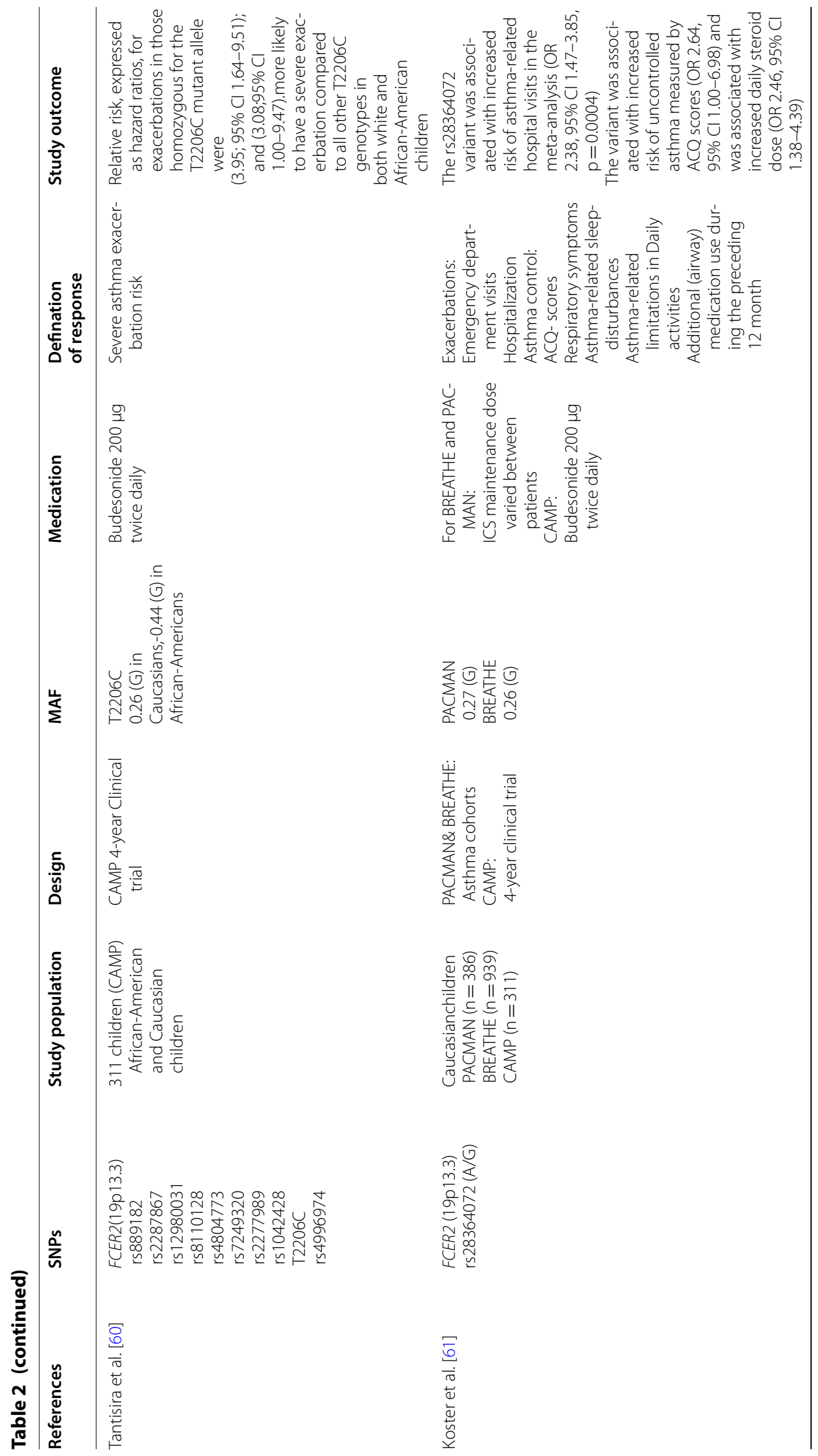




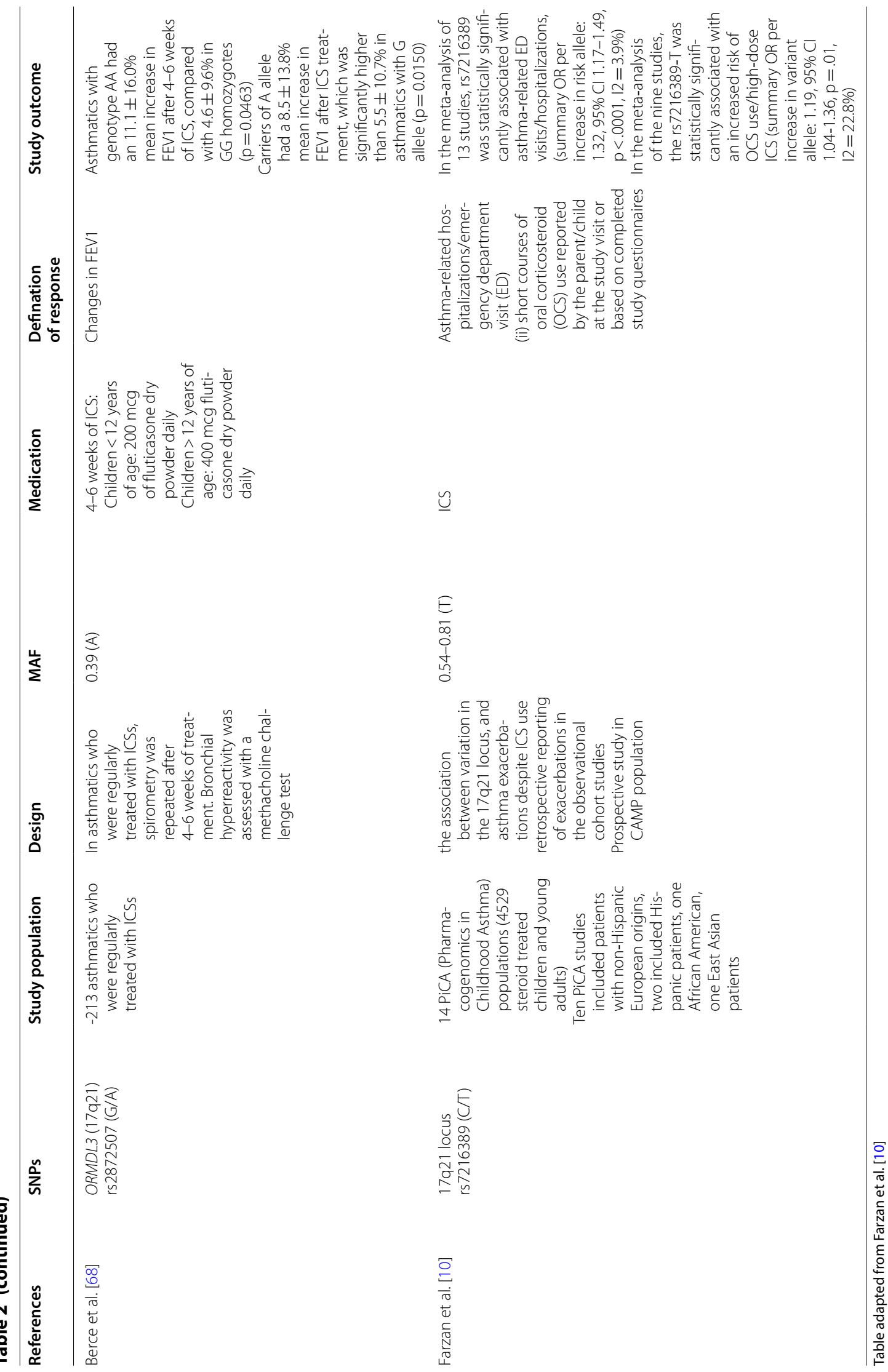


In a Chinese population of 418 adult asthmatics receiving 24 weeks of ICS treatment, rs37973 was independently associated with lower ICS response measured with FEV1 changes [44]. Percentages of homozygotes for the wild-type allele who had $>5 \%$ FEV1 change were more common than homozygotes of the rare allele (AA $67.01 \%$ vs. GG 49.49\%, p <.05) [44].

In another Chinese study, $\mathrm{Hu}$ et al. evaluated the association of 24 SNPs within the GLCCI1 gene with ICS response. They included 180 healthy individuals and 182 adult asthmatic patients from Chinese Han population. In line with the previous findings, patients homozygous for the $G$ allele had significantly poorer improvements in their lung function compared to the heterozygotes and homozygotes for the A allele after 12 weeks of treatment with ICS [23]. Contrasting findings were shown in a study in 208 Slovenian adults with atopic and nonatopic asthma. FEV1\% predicted was higher in patients with GG genotype than patients with the AG or AA genotype; after 3 months treatment FEV1\% predicted change: $7.5 \%$ in patients homozygous for the $\mathrm{G}$ allele versus $4 \%$ (patients with AG/AA genotype), p value: 0.049. After 3 years of treatment, similar effects were observed; FEV1 \%pred 7\% (GG) versus 3.5\% (AG/AA), p-value: 0.041) [45].

However, in a study we performed in 82 Turkish children with moderate-severe asthma exacerbation, we were unable to show any association between FEV1 increase after $4 \mathrm{~h}$ of single-high-dose ICS and variation at GLCCI1 rs37973, rs3099266, rs2305089 genotypes [43].

Therefore, seven candidate gene studies have tried to replicate the results of the original GWAS. Interestingly, three studies that included East Asian populations (Japanese and Chinese) could positively replicate the results of the GWAS. Although the exact definition of the outcomes was different (annual decline in FEV1 and improvements in FEV1), all three showed that the G allele was associated with poor lung function outcomes. Interestingly, the minor allele frequency of rs37973 in East Asian patients was comparable to patients of Caucasian ethnicity. However, in contrast to the non-Hispanic white subjects in the GWAS, where LD was almost perfect between rs37972 and rs37973, in the study by $\mathrm{Hu}$ et al. this LD was far from perfect.

\section{NR3C1}

Glucocorticoids bind to their receptors in the cytosol and after the transfer of glucocorticoid receptor complex to the nucleus, they regulate expression of the genes involved in the inflammatory pathways $[62,63]$. Therefore, due to its central role in glucocorticoid signaling pathway, $N R 3 C 1$, the gene encoding GR, has been the center of attention in numerous pharmacogenomics studies [63, 64]. By 2015, two studies had investigated the role of SNPs in the NR3C1 in glucocorticoid sensitivity and response. However, only one study in adults hadfound an association between anSNP within this gene (rs41423247) and response (defined by changes in FEV1 predicted) to prednisolone but not ICS. In-vitro and in vivo models have shown that the $G$ allele of the rs41423247 locus at the NR3C1 gene was associated with hypersensitivity to glucocorticoids $[65,66]$.

Recently, our group reported a significant association between rs41423247 and improvements in FEV1 after $4 \mathrm{~h}$ upon a single high-dose of ICS $(4000 \mu \mathrm{g}$ FP) in 82 Turkish children with moderate-to-severe asthma exacerbations [43]. Children with the GG genotype at rs41423247 had a higher improvement in FEV1 [24.2\% (11.5-36.3)] compared to those with CG+CC, [7.9\% (6.1-24.6) $(\mathrm{p}=0.006)]$.

\section{7q21locus}

$17 \mathrm{q} 21$ is the most consistently identified locus associated with asthma onset in children and severe asthma, and it has also been linked to ICS response. By 2015, two studies examined the association between SNPs within the 17q21 locus and response to ICS [67, 68], though different variants were studied. A Slovenian study showed that asthmatic children treated with ICS showed a better improvement in FEV1\% when they were homozygous for the AA genotype at rs 2872507 at $17 \mathrm{q} 21$ compared to patients with AG or GG genotypes $(13.3 \%$ vs. $7.0 \%$ vs. $4.9 \%$ respectively). In addition, a post hoc exome array analysis of Dutch children who participated in the Children Asthma Therapy Optimal (CATO) trial, showed that several variants in the 17q12-21 locus were found nominally associated with treatment response to ICS (based on FEV1\% improvement or BHR during ICS treatment). The strongest association in this region was found for rs72821893 in KRT25.

In 2018, one of the largest pharmacogenomics studies [48] so far was performed by the international Pharmacogenomics in Childhood Asthma (PiCA) consortium [69]. In this study, more than 4000 children were included from 13 different studies. Genetic variation at position rs7216389 in the17q21 locus was found to be associated with an increased risk of OCS use and asthma-related hospitalizations/ER visits despite ICS use.

\section{Discussion}

In the past 3 years, nine additional pharmacogenomics studies on ICS have been published, of which three GWAS. Although there is few overlap between identified variants and applied methodologies vary largely, in vitro and/or in silico analyses provide additional evidence that genes discovered in GWAS (e.g. GLCCI1, FBXL7, T gene, 
ALLC, CMTR1) might play a direct or indirect role in asthma/treatment response pathways.

Candidate gene analysis, on the other hand identified five SNPs within four genes (CRHR1: rs242941, rs1876828; GLCCI1: rs37973; FCER2: rs28364072 and TBX21: rs2240017) that were positively replicated at least once. In line with the previous systematic review by Farzan et al., most consistent results were obtained for $F C \varepsilon R 2$ (rs28364072) and TBX21(rs2240017) [46, 51, 58, $60,61]$. The only gene that showed a positive association in both GWAS and candidate gene analyses was GLCCI1 $[12,23,44,45,54]$. However, it should be noted that this may be partly due to the fact the candidate gene studies were undertaken after identification of GLCCI1 in a GWAS analysis.

Consistent significant associations were replicated between $F C \varepsilon R 2$ rs28364072 and poor ICS response measured by exacerbations in two long follow up childhood studies [60, 61], asthma symptoms measured by ACQ in one long follow up childhood study [61], and lung function in one study [51] in asthmatic children. Moreover, supporting clinical findings, functional data related with FCER2 provided a mechanistic basis for the observed associations with severe exacerbations. This variation in FCER2, T2206C, was associated with decreased FCER2 expression and can adversely affect normal negative feedback in the control of IgE synthesis and action [60]. Moreover, it has been shown that the highest IgE levels were found in subjects both homozygous for the T2206C variant and taking ICSs, demonstrating a significant steroid-genotype interaction. This may actually be connected with the observation that higher IgE levels are associated with increased frequency of exacerbations [70], and hospitalizations [71, 72] in children with asthma.

Both studies investigating TBX21 H33Q and ICS response showed significant association measured by two different outcomes: improvement in BHR in one childhood study of 4 years duration [58], and asthma control status in a 5-12 weeks adult study [46]. Since BHR and asthma control level are related to the quality of life in asthma patients and prognosis of asthma, genetic variation in TBX21 may be important for asthma phenotypes. This finding was further supported by a functional study that showed that the TBX21 variant increases $T$ helper 1 and decreases $\mathrm{T}$ helper 2 cytokine expression compared to wild type [58]. However, we were not able show any association between TBX21 H33Q and FEV1 $4 \mathrm{~h}$ after single-high-dose ICS in children with moderate-severe asthma exacerbation [43]. This difference may be due to different outcome parameter or different study design or different doses and duration of ICS.

Asthma is a very heterogeneous disease with various phenotypes and underlying disease pathways. Recent studies have emphasized the importance of defining the correct phenotype in successful asthma treatment. A good characterization of patients as well has a standardized definition of treatment response is therefore extremely important. Since most pharmacogenetic studies are underpowered, collaboration is inevitable. Novel consortia, such as the Pharmacogenomics in Childhood Asthma (PiCA) consortium, are emerging $[69,72]$ and are able to conduct large-scale GWAS meta-analyses, while performing sensitivity analyses for specific subgroups. This might lead to novel insights on the generalizability of findings between different populations, as well as more power to identify novel genetic variants.

In order to increase the utility of the pahramacogenomic studies in asthma the data that have emerged from GWAS, candidate gene, and mechanistic candidates should be evaluated together. This approach will allow the discovery not only of pharmacologic agents that directly target the disease asthma but also other pathways and biomarkers that are indirectly associated with or increase the risk of the disease such as atopy, eosinophils, bronchial hyperreactivity, pulmonary functions, and NO [73].

Pharmacogenomics may produce very important information for the practicing clinician. Predicting the drug response based on genetic testing has implications with respect to not only providing the best treatment but also preventing the adverse events that may be associated especially with higher doses and systemic CS [74, 75]. On a larger scale it may have tremendous effect on pharmacoeconomics by decreasing unnecessary medication use as well as by having a positive impact on the cost of the disease, as has been shown in other disease areas [76]. Even though ongoing international attempts such as "Ubiquitous Pharmacogenomics (U-PGx)" project "An Horizon2020 Program to Drive Pharmacogenomics into Clinical Practice" that is going on in seven European countries [77] holds promise, we are far from using pharmacogenomics data in clinical asthma practice. In contrast to long-acting beta-2 agonists [78], response to corticosteroids might be too complex to be mainly driven by a few genetic variants. Nevertheless, pharmacogenomics studies still might provide useful insights in underlying pathways or identify novel drug targets, especially when combined with other-omics layers (e.g. epigenomics, transcriptomics, microbiomics, breathomics) or assessing the interaction with the environmental factors using genome-wide interaction studies in well characterized patient populations [79]. Especially with the emergence of novel expensive biologics for patients with a poor response to ICS, it is of great importance to assess at an early stage which patients have an intrinsic poor response to ICS and will be eligible candidates for 
these novel targeted treatments. Genomics might, at least partly, help to answer this question.

\section{Abbreviations}

ICS: inhaled corticosteroid; SNP: single nucleotide polymorphism; GWAS: genome wide association studies; SHARP: Single-Nucleotide Polymorphism Health Association-Asthma Resource Project; FEV1: forced expiratory volume in one second; FP: fluticasone propionate; FF: fluticasone furoate; CAMP: Childhood Asthma Management Program; GLCCI1: glucocorticoid-induced transcript 1 protein; FBXL7: F-box and leucine-rich repeat protein 7; ALLC: allantoicase gene; CMTR1: cap methyltransferase 1;TRIM24: tripartite motif containing 24: MAGI2: Membrane Associated Guanylate Kinase; NR3C1: nuclear receptor subfamily 3 group C member 1; CRHR1: corticotropin releasing hormone receptor 1; FCER2: FC fragment of IgE, low-affinity II, receptor for (CD23); ADRB2: Adrenoceptor beta 2; TBX21:T-box 21.

\section{Authors' contributions}

OZK, OMK, EB, CK, HA: made substantial contributions to conception and design, acquisition of data, analysis and interpretation of data. OZK, OMK, EB, CK, HA: been involved in drafting the manuscript. OZK, OMK, NF, AHMvdZ, MEW, SJV been involved in revising the manuscript critically for important intellectual content and given final approval of the version to be published. Each author have participated sufficiently in the work to take public responsibility for appropriate portions of the content; and agreed to be accountable for all aspects of the work in ensuring that questions related to the accuracy or integrity of any part of the work are appropriately investigated and resolved. All authors read and approved the final manscript.

\section{Author details}

${ }^{1}$ Paediatric Allergy and Immunology Department, School of Medicine, Gaziantep University, Gaziantep, Turkey. ${ }^{2}$ Department of Respiratory Medicine, University of Amsterdam, Amsterdam UMC, Meibergdreef 9, Amsterdam, Netherlands. ${ }^{3}$ Pediatric Allergy and Asthma Unit, Hacettepe University School of Medicine, 06100 Ankara, Turkey. ${ }^{4}$ Department of Molecular Biology, Faculty of Sciences, Hacettepe University, Ankara, Turkey. ${ }^{5}$ Department of Pediatric Respiratory Medicine and Allergy, University of Amsterdam, Amsterdam UMC, Meibergdreef 9, Amsterdam, Netherlands. ${ }^{6}$ Department of Medicine, National Jewish Health, Denver, CO, USA.

\section{Competing interests}

The authors declare that they have no competing interests.

\section{Consent for publication}

Not applicable.

Ethics approval and consent to participate

Not applicable.

\section{Funding}

There is no funding.

\section{Publisher's Note}

Springer Nature remains neutral with regard to jurisdictional claims in published maps and institutional affiliations.

Received: 26 September 2018 Accepted: 16 November 2018 Published online: 09 January 2019

\section{References}

1. Global Initiative for Asthma (GINA). From the global strategy for asthma management and prevention, global initiative for asthma (GINA), 2018. http://www.ginasthma.org/.

2. Szefler SJ, Phillips BR, Martinez FD, et al. Characterization of within-subject responses to fluticasone and montelukast in childhood asthma. J Allergy Clinlmmunol. 2005:115:233-42.
3. Malmstrom K, Rodriguez-GomezG G, Guerra J, et al. Oral montelukast, inhaled beclomethasone, and placebo for chronic asthma: a randomized, controlled trial. Montelukast/Beclomethasone Study Group. Ann Intern Med. 1999;130:487-95.

4. Drazen JM, Silverman EK, Lee TH. Heterogeneity of therapeutic responses in asthma. Br Med Bull. 2000;56:1054-70.

5. Chung KF, Godard P, Adelroth E, et al. Difficult/therapy-resistant asthma: the need for an integrated approach to define clinical phenotypes, evaluate risk factors, understand pathophysiology and find novel therapies. ERS Task Force on Difficult/Therapy-Resistant Asthma. European Respiratory Society. Eur Respir J. 1999;13:1198-208.

6. Haughney J, Price D, Kaplan A, et al. Achieving asthma control in practice: understanding the reasons for poor control. Respir Med. 2008;102:1681-93.

7. McGhan SL, MacDonald C, James DE, et al. Factors associated with poor asthma control in children aged five to 13 years. Can Respir J. 2006;13:23-9.

8. Lima JJ, Blake KV, Tantisira KG, Weiss ST. Pharmacogenetics of asthma. Curr Opin Pulm Med. 2009;15:57-62

9. Palmer LJ, Silverman ES, Weiss ST, Drazen JM. Pharmacogenetics of asthma. Am J Respir Crit Care Med. 2002;165:861-6.

10. Farzan N, Vijverberg SJ, Arets HG, Raaijmakers JA, Maitland-van der Zee $\mathrm{AH}$. Pharmacogenomics of inhaled corticosteroids and leukotriene modifiers: a systematic review. Clin Exp Allergy. 2017:47:271-93.

11. Moher D, Liberati A, Tetzlaff J, Altman DG, PRISMA Group. Preferred reporting items for systematic reviews and meta-analyses: the PRISMA statement. J Clin Epidemiol. 2009:62:1006-12.

12. Tantisira KG, Lasky-Su J, Harada M, et al. Genomewide association between GLCCI1 and response to glucocorticoid therapy in asthma. N Engl J Med. 2011;365:1173-83.

13. Tantisira KG, Damask A, Szefler SJ, et al. Genome-wide association identifies the T gene as a novel asthma pharmacogenetic locus. Am J Respir Crit Care Med. 2012;185:1286-91.

14. Park H-W, Dahlin A, Tse S, et al. Genetic predictors associated with improvement of asthma symptoms in response to inhaled corticosteroids. J Allergy Clin Immunol. 2014;133(664-9):e5.

15. Park T-J, Park J-S, Cheong HS, et al. Genome-wide association study identifies ALLC polymorphisms correlated with FEV1 change by corticosteroid. Clin Chim Acta. 2014;436:20-6.

16. Wang Y, Tong C, Wang Z, Wang Z, Mauger D, Tantisira KG, Israel E, Szefler SJ, Chinchilli VM, Boushey HA, Lazarus SC, Lemanske RF, Wu R. Pharmacodynamic genome-wide association study identifies new responsive loci for glucocorticoid intervention in asthma. Pharmacogenomics J. 2015;15:422-9.

17. Dahlin A, Denny J, Roden DM, et al. CMTR1 is associated with increased asthma exacerbations in patients taking inhaled corticosteroids. Immun Inflamm Dis. 2015:3:350-9.

18. Mosteller M, Hosking L, Murphy K, et al. No evidence of large genetic effects on steroid response in asthma patients. J Allergy Clin Immunol. 2017;139(797-803):e7.

19. Wu RL, Tong CF, Mauger D, Mauger D, Tantisira K, Szefler SJ, et al. A conceptual framework for pharmacodynamic genome-wide association studies in pharmacogenomics. Drug Discov Today. 2011;16:804-90.

20. Yeh TY, Sbodio Jl, Nguyen MT, Meyer TN, Lee RM, Chi NW. Tankyrase-1 over expression reduces genotoxin-induced cell death by inhibiting PARP1. Mol Cell Biochem. 2005;276:183-92.

21. Kuschel L, Hansel A, Schonherr R, Weissbach H, Brot N, Hoshi T, et al. Molecular cloning and functional expression of a human peptide methionine sulfoxidereductase (hMsrA). FEBS Lett. 1999;456:17-21.

22. Chapman MS, Qu N, Pascoe S, Chen WX, Apostol C, Gordon D, Miesfeld $\mathrm{RL}$. Isolation of differentially expressed sequence tags from steroidresponsive cells using mRNA differential display. Mol Cell Endocrinol. 1995; 108:R1-7

23. Hu C, Xun Q, Li X, He R, Lu R, Zhang S, Hu X, Feng J. GLCCl1 variation is associated with asthma susceptibility and inhaled corticosteroid response in a Chinese Han population. Arch Med Res. 2016:47:118-25.

24. Coon TA, Glasser JR, Mallampalli RK, Chen BB. Novel E3 ligase component FBXL7 ubiquitinates and degrades Aurora A, causing mitotic arrest. Cell Cycle. 2012;11:721-9.

25. Tyers $M$, Willems AR. One ring to rule a superfamily of E3 ubiquitin ligases. Science. 1999:284:601, 603-4. 
26. Liu Y, Lear T, Zhao Y, Zhao J, Zou C, Chen BB, Mallampalli RK. F-box protein Fbxl18 mediates polyubiquitylation and proteasomal degradation of the pro-apoptotic SCF subunit Fbxl7. Cell Death Dis. 2015;6:e1630.

27. Liu Y, Lear T, lannone O, Shiva S, Corey C, Rajbhandari S, Jerome J, Chen BB, Mallampalli RK. The proapoptotic F-box protein Fbxl7 regulates mitochondrial function by mediating the ubiquitylation and proteasomal degradation of survivin. J Biol Chem. 2015;290:11843-52.

28. Skaar JR, Pagan JK, Pagano M. Mechanisms and function of substrate recruitment by F-box proteins. Nat Rev Mol Cell Biol. 2013;14:369-81.

29. Galan JM, Peter M. Ubiquitin-dependent degradation of multiple F-box proteins by an autocatalytic mechanism. Proc Natl Acad Sci USA. 1999;96:9124-9.

30. Bollag RJ, Siegfried Z, Cebra-Thomas JA, Garvey N, Davison EM, Silver LM. An ancient family of embryonically expressed mouse genes sharing a conserved protein motif with the T locus. Nat Genet. 1994;7:383-9.

31. Hoffmann A, Czichos S, Kaps C, Bächner D, Mayer H, Kurkalli BG, Zilberman Y, Turgeman G, Pelled G, Gross G, Gazit D. The T-box transcription factor Brachyury mediates cartilage development in mesenchymal stem cell line C3H10T1/2. J Cell Sci. 2002;115:769-81.

32. Donn R, Berry A, Stevens A, Farrow S, Betts J, Stevens R, Clayton C, Wang J, Warnock L, Worthington J, Scott L, Graham S, Ray D. Use of gene expression profiling to identify a novel glucocorticoid sensitivity determining gene. BMPRIII. FASEB J. 2007;21:402-14.

33. Pollett JB, Trudel S, Stern D, Li ZH, Stewart AK. Overexpression of the myeloma-associated oncogene fibroblast growth factor receptor 3 confers dexamethasone resistance. Blood. 2002;100:3819-21.

34. van der Plaat DA, de Jong K, de Vries M, van Diemen CC, Nedeljković I, Amin N, Kromhout H, Biobank-based Integrative Omics Study Consortium, Vermeulen R, Postma DS, van Duijn CM, Boezen HM, Vonk JM. Occupational exposure to pesticides is associated with differential DNA methylation. Occup Environ Med. 2018;75:427-35.

35. Vigetti D, Pollegioni L, Monetti C, Prati M, Bernardini G, Gornati R. Property comparison of recombinant amphibian and mammalian allantoicases. FEBS Lett. 2002;512:323-8.

36. Repapi E, Sayers I, Wain LV, et al. Genome-wide association study identifies five loci associated with lung function. Nat Genet. 2010;42:36-44.

37. Postma DS, Meyers DA, Jongepier $\mathrm{H}$, et al. Genomewide screen for pulmonary function in 200 families ascertained for asthma. Am J Respir Crit Care Med. 2005;172:446-52.

38. Howard TD, Postma DS, Hawkins GA, et al. Fine mapping of an lgEcontrolling gene on chromosome 2q:analysis of CTLA4 and CD28. J Allergy Clin Immunol. 2002;1 10:743-51.

39. Bélanger F, Stepinski J, Darzynkiewicz E, Pelletier J. Characterization of hMTr1, a human Cap1 2'-O-ribose methyltransferase. J Biol Chem. 2010;285:33037-44.

40. Gu M, Lima CD. Processing the message: structural insights into capping and decapping mRNA. Curr Opin Struct Biol. 2005;15:99-106.

41. Kato A, Homma T, Batchelor J, Hashimoto N, Imai S, Wakiguchi H, Saito H, Matsumoto K. Interferon-alpha/beta receptor-mediated selective induction of a gene cluster by CpGoligodeoxynucleotide 2006. BMC Immunol. 2003;4:8.

42. Tan WC. Viruses in asthma exacerbations. Curr Opin Pulm Med. 2005;11:21-6

43. Keskin O, Uluca U, Birben E, Coşkun Y, Ozkars MY, Keskin M, Kucukosmanoglu E, Kalayci O. Genetic associations of the response to inhaled corticosteroids in children during an asthma exacerbation. Pediatr Allergy Immunol. 2016:27:507-13.

44. Xu Y, Wu H, Wu X, Xu Y, Zhao J, Xie J, Yu J. GLCCI1 rs37973: a potential genetic predictor of therapeutic response to inhaled corticosteroids in Chinese asthma patients. Medicine (Baltimore). 2017:96:e9442.

45. Rijavec M, Žavbi M, Lopert A, Fležar M, Korošec P. GLCCl1 polymorphism rs37973 and response to treatment of asthma with inhaled corticosteroids. J Investig Allergol Clin Immunol. 2018;28:165-71.

46. Ye YM, Lee HY, Kim SH, Jee YK, Lee SK, Lee SH, Park HS. Pharmacogenetic study of the effects of NK2R G231E G > A and TBX21 H33Q C > G polymorphisms on asthma control with inhaled corticosteroid treatment. J Clin Pharm Ther. 2009;34:693-701.

47. Turner S, Francis B, Vijverberg S, Pino-Yanes M, Maitland-van der Zee AH, Basu K, Bignell L, Mukhopadhyay S, Tavendale R, Palmer C, Hawcutt D, Pirmohamed M, Burchard EG, Lipworth B, Pharmacogenomics in Childhood Asthma Consortium. Childhood asthma exacerbations and the
Arg 16 32-receptor polymorphism: a meta-analysis stratified by treatment. J Allergy Clin Immunol. 2016;138:107.e5-113.e5.

48. Farzan N, Vijverberg SJ, Hernandez-Pacheco N, Bel EHD, Berce V, Bønnelykke K, Bisgaard H, Burchard EG, Canino G, Celedón JC, Chew FT, Chiang WC, Cloutier MM, Forno E, Francis B, Hawcutt DB, Herrera-Luis E, Kabesch M, Karimi L, Melén E, Mukhopadhyay S, Merid SK, Palmer CN, Pino-Yanes M, Pirmohamed M, Potočnik U, Repnik K, Schieck M, Sevelsted A, Sio YY, Smyth RL, Soares P, Söderhäll C, Tantisira KG, Tavendale R, Tse SM, Turner S, Verhamme KM, Maitland-van der Zee AH. 17q21 variant increases the risk of exacerbations in asthmatic children despite inhaled corticosteroids use. Allergy. 2018 Jun 9. https://doi.org/10.1111/all.13499. [Epubahead of print].

49. Tantisira KG, Lake S, Silverman ES, Palmer LJ, Lazarus R, Silverman EK, et al. Corticosteroid pharmacogenetics: association of sequence variants in CRHR1 with improved lung function in asthmatics treated with inhaled corticosteroids. Hum Mol Genet. 2004;13:1353-9.

50. Dijkstra A, Koppelman GH, Vonk JM, Bruinenberg M, Schouten JP, Postma DS. Pharmacogenomics and outcome of asthma: no clinical application for long-term steroid effects by CRHR1 polymorphisms. J Allergy Clinlmmunol. 2008:121:1510-3.

51. Rogers AJ, Tantisira KG, Fuhlbrigge AL, Litonjua AA, Lasky-Su JA, Szefler SJ, Strunk RC, Zeiger RS, Weiss ST. Predictors of poor response during asthma therapy differ with definition of outcome. Pharmacogenomics. 2009;10:1231-42.

52. Mougey EB, Chen C, Tantisira KG, Blake KV, Peters SP, Wise RA, Weiss ST, Lima JJ. Pharmacogenetics of asthma controller treatment. Pharmacogenomics J. 2013;13:242-50.

53. Hosking L, Bleecker E, Ghosh S, Yeo A, Jacques L, Mosteller M, Meyers D. GLCCI1 rs37973 does not influence treatment response to inhaled corticosteroids in white subjects with asthma. J Allergy Clin Immunol. 2014:133:587-9.

54. Izuhara Y, Matsumoto H, Kanemitsu Y, et al. GLCCI1 variant accelerates pulmonary function decline in patients with asthma receiving inhaled corticosteroids. Allergy. 2014;69:668-73.

55. Vijverberg SJ, Tavendale R, Leusink M, Koenderman L, Raaijmakers JA, Postma DS, Koppelman GH, Turner SW, Mukhopadhyay S, Palmer CN, Maitland-van der Zee AH. Pharmacogenetic analysis of GLCCI1 in three north European pediatric asthma populations with a reported use of inhaled corticosteroids. Pharmacogenomics. 2014;15:799-806.

56. Szczepankiewicz A, Breborowicz A, Sobkowiak P, Popiel A. No association of glucocorticoid receptor polymorphisms with asthma and response to glucocorticoids. Adv Med Sci. 2008;53:245-50.

57. Vijverberg SJ, Koster ES, Tavendale R, Leusink M, Koenderman L, Raaijmakers JA, Postma DS, Koppelman GH, Turner SW, Mukhopadhyay S, Tse SM, Tantisira KG, Hawcutt DB, Francis B, Pirmohamed M, Pino-Yanes M, Eng C, Burchard EG, Palmer CN, Maitland-van der Zee AH. ST13 polymorphisms and their effect on exacerbations in steroid-treated asthmatic children and young adults. Clin Exp Allergy. 2015;45:1051-9.

58. Tantisira KG, Hwang ES, Raby BA, Silverman ES, Lake SL, Richter BG, Peng SL, Drazen JM, Glimcher LH, Weiss ST. TBX21: a functional variant predicts improvement in asthma with the use of inhaled corticosteroids. Proc Nat Acad Sci USA. 2004;101:18099-104.

59. Lopert A, Rijavec M, Zavbi M, Korošec P, Fležar M. Asthma treatment outcome in adults is associated with rs9910408 in TBX21 gene. Sci Rep. 2013:3:2915

60. Tantisira KG, Silverman ES, Mariani TJ, Xu J, Richter BG, Klanderman BJ, Litonjua AA, Lazarus R, Rosenwasser LJ, Fuhlbrigge AL, Weiss ST. FCER2: a pharmacogenetic basis for severe exacerbations in children with asthma. J Allergy Clin Immunol. 2007;120:1285-91.

61. Koster ES, Maitland-van der Zee AH, Tavendale R, Mukhopadhyay S, Vijverberg SJ, Raaijmakers JA, Palmer CN. FCER2 T2206C variant associated with chronic symptoms and exacerbations in steroid-treated asthmatic children. Allergy. 2011;66:1546-52.

62. Wright AP, Zilliacus J, McEwan IJ, et al. Structure and function of the Glucocorticoid receptor. J Steroid Biochem Mol Biol. 1993;47:11-9.

63. Oakley RH, Cidlowski JA. The biology of the glucocorticoid receptor: new signaling mechanisms in health and disease. J Allergy Clinlmmunol. 2013;132:1033-44.

64. Lu NZ, Cidlowski JA. The origin and functions of multiple human glucocorticoid receptor isoforms. Ann N Y Acad Sci. 2004;1024:102-23. 
65. van Rossum EF, Koper JW, van den Beld AW, et al. Identification of the Bcll polymorphism in the glucocorticoid receptor gene: association with sensitivity to glucocorticoids in vivo and body mass index. Clin Endocrinol (Oxf). 2003;59:585-92.

66. Cuzzoni E, De ludicibus S, Bartoli F, Ventura A, Decorti G. Association between Bcll polymorphism in the NR3C1 gene and in vitro individual variations in lymphocyte responses to methylprednisolone. $\mathrm{Br} J \mathrm{Clin}$ Pharmacol. 2012;73:651-5.

67. Leusink M, Vijverberg SJ, Koenderman L, et al. Genetic variation in uncontrolled childhood asthma despite ICS treatment. Pharmacogenomics J. 2016;16:158-63.

68. Berce V, Kozmus CE, Potočnik U. Association among ORMDL3 gene expression, 17q21 polymorphism and response to treatment with inhaled corticosteroids in children with asthma. Pharmacogenomics J. 2013;13:523-9.

69. Farzan N, Vijverberg SJ, Andiappan AK, Arianto L, Berce V, Blanca-López N, Bisgaard H, Bønnelykke K, Burchard EG, Campo P, Canino G, Carleton B, Celedón JC, Chew FT, Chiang WC, Cloutier MM, Daley D, Den Dekker HT, Dijk FN, Duijts L, Flores C, Forno E, Hawcutt DB, Hernandez-Pacheco N, de Jongste JC, Kabesch M, Koppelman GH, Manolopoulos VG, Melén E, Mukhopadhyay S, Nilsson S, Palmer CN, Pino-Yanes M, Pirmohamed M, Potočnik U, Raaijmakers JA, Repnik K, Schieck M, Sio YY, Smyth RL, Szalai C, Tantisira KG, Turner S, van der Schee MP, Verhamme KM, Maitland-van der Zee $\mathrm{AH}$. Rationale and design of the multiethnic Pharmacogenomics in Childhood Asthma consortium. Pharmacogenomics. 2017;18:931-43.

70. Wever-Hess J, Kouwenberg JM, Duiverman EJ, Hermans J, Wever AM. Risk factors for exacerbations and hospital admissions in asthma of early childhood. Pediatr Pulmonol. 2000;29:250-6.

71. Green RM, Custovic A, Sanderson G, Hunter J, Johnston SL, Woodcock A Synergism between allergens and viruses and risk of hospital admission with asthma: case-control study. BMJ. 2002;324:763.
72. Siroux V, Oryszczyn MP, Paty E, Kauffmann F, Pison C, Vervloet D, et al. Relationships of allergic sensitization, total immunoglobulin $E$ and blood eosinophils to asthma severity in children of the EGEA Study. Clin Exp Allergy. 2003;33:746-51.

73. Khera AV, Kathiresan S. Genetics of coronary artery disease: discovery, biology and clinical translation. Nat Rev Genet. 2017;18:331-44.

74. O'Neill S, Sweeney J, Patterson CC, Menzies-Gow A, Niven R, Mansur AH, Bucknall C, Chaudhuri R, Thomson NC, Brightling CE, O'Neill C, Heaney LG, British Thoracic Society Difficult Asthma Network. The cost of treating severe refractory asthma in the UK: an economic analysis from the British Thoracic Society Difficult Asthma Registry. Thorax. 2015;70:376-8.

75. Barry LE, Sweeney J, O'Neill C, Price D, Heaney LG. The cost of systemic corticosteroid-induced morbidity in severe asthma: a health economic analysis. Respir Res. 2017;18:129.

76. Verhoef TI, Redekop WK, Hasrat F, de Boer A, Maitland-van der Zee AH. Cost effectiveness of new oral anticoagulants for stroke prevention in patients with atrial fibrillation in two different European healthcare settings. Am J Cardiovasc Drugs. 2014;14:451-62.

77. Manson LE, van der Wouden CH, Swen JJ, Guchelaar HJ. The ubiquitous pharmacogenomics consortium: making effective treatment optimization accessible to every European citizen. Pharmacogenomics. 2017; 18:1041-5.

78. Vijverberg SJ, Pijnenburg MW, Hövels AM, Koppelman GH, Maitland-van der Zee $\mathrm{AH}$. The need for precision medicine clinical trials in childhood asthma: rationale and design of the PUFFIN trial. Pharmacogenomics. 2017:18:393-401.

79. Vijverberg SJH, Farzan N, Slob EMA, Neerincx AH, Maitland-van der Zee $\mathrm{AH}$. Treatment response heterogeneity in asthma: the role of genetic variation. Expert Rev Respir Med. 2018;12:55-65.
Ready to submit your research? Choose BMC and benefit from:

- fast, convenient online submission

- thorough peer review by experienced researchers in your field

- rapid publication on acceptance

- support for research data, including large and complex data types

- gold Open Access which fosters wider collaboration and increased citations

- maximum visibility for your research: over 100M website views per year

At BMC, research is always in progress.

Learn more biomedcentral.com/submissions 